\title{
PEMBENTUKAN DAERAH LAWAS SEBAGAI DAERAH TERAKHIR BERSAMA KERAJAAN SARAWAK (THE FORMATION OF LAWAS DISTRICT AS A LAST DISTRICT IN THE SARAWAK GOVERNMENT)
}

\author{
Habid's Buhigiba bin Mohamad Bustamam \\ Suffian Mansor \\ Mohd. Bin Shamsuddin
}

\begin{abstract}
Abstrak
Artikel ini membincangkan sejarah pembentukan Daerah Lawas dan bagaimanakah daerah ini menyertai Kerajaan Sarawak sebagai daerah yang terakhir sejak bermula peluasan kuasa Sarawak tahun 1841. Perbincangan akan dibahagikan kepada dua bahagian berasaskan peristiwa di sungai Trusan dan sungai Lawas. Semasa pentadbiran Brunei semua pemilikan tanah di Sabah dan Sarawak dibahagikan mengikut sistem sungai Kerajaan, sungai Kuripan dan sungai Tulin. Persaingan berlaku di antara Kerajaan Sarawak dan Syarikat Borneo Utara British (SBUB) untuk mengambil tanah di sekitar kawasan Teluk Brunei hingga akhir abad ke-20. Bagaimanakah persaingan di antara kedua-dua kerajaan dan penglibatan wazir di Brunei dalam isu Sungai Trusan membawa kepada penyerahan Sungai Trusan kepada Kerajaan Sarawak? Apakah masalah di Sungai Lawas yang menyebabkan Kerajaan SBUB menyerahkan kawasan tersebut kepada Kerajaan Sarawak? Bagaimanakah Kerajaan Sarawak menyelesaikan tuntutan para pengiran dan Brooke Johnson bagi memenuhi syarat Kerajaan British bagi mengambil Sungai Lawas? Dapatan kajian menunjukkan bahawa penolakan penduduk Sungai Lawas menjadi elemen penting yang membawa kepada penyerahan Sungai Lawas kepada Kerajaan Sarawak. Pengambilan kedua-dua sungai oleh Kerajaan Sarawak telah berjaya mewujudkan keamanan dan mengekalkan kestabilan dalam kehidupan penduduk di Sungai Trusan dan Sungai Lawas.
\end{abstract}

\begin{abstract}
This article discusses the formation of Lawas District and how it joined the Sarawak Government as the last district in Sarawak's expansion since 1841. The discussion is divided into two parts based on the event at Sungai Trusan and Sungai Lawas. Under Brunei's administration, all state lands were divided into three categories, namely sungai Kerajaan, sungai Kuripan and sungai Tulin. The Sarawak Government and the British North Borneo Company competed with each other for the lands in the Gulf of Brunei until the end of the $20^{\text {th }}$ century. How did the competition between these two governments and the involvement of Wazir in Brunei lead to the fall of Sungai Trusan to the Sarawak Government? What was the problem in Sungai Lawas that caused the Company Government to cede the area to the Sarawak Government? How did the Sarawak Government resolve the claims made by the pengirans and Brooke Johnson to fulfill the British Government's requirement to take over the Lawas River? The findings show that the protest from the people of Sungai Lawas was an important factor leading to the submission of Sungai Lawas to the Sarawak Government. The acquisition of both rivers
\end{abstract}


by the Sarawak Government helped establish peace and maintain stability among the residents of Sungai Trusan and Sungai Lawas.

\section{Pengenalan}

Pada hari ini Daerah Lawas diletakkan dalam Bahagian Limbang, Sarawak. Terdapat dua sungai utama yang membentuk Daerah Lawas iaitu Sungai Lawas dan Sungai Trusan. Kedua-dua sungai ini diambil oleh Raja Brooke pada dua waktu yang berbeza iaitu tahun 1886 dan 1906. Sungai Trusan dan Sungai Lawas merupakan sungai yang terletak di utara sungai Pandaruan, Brunei (Temburong). Kedudukan Daerah Lawas adalah di antara kawasan pentadbiran Temburong yang dimiliki oleh negara Brunei Darussalam di selatan dan Daerah Sipitang, Sabah di bahagian utara. Bentuk muka bumi Daerah Lawas adalah bergunung ganang dan berbukit bukau. Masyarakat yang mendiami Daerah Lawas terdiri daripada orang Melayu Brunei, Kedayan dan Lun Bawang. ${ }^{1}$ Kegiatan utama penduduk di Lawas kebanyakannya dalam aktiviti pertanian, penternakan dan nelayan sungai secara kecil-kecilan. Orang Melayu Brunei dan Kedayan yang tinggal dipesisir sungai lebih banyak terlibat dengan aktiviti pertanian dan nelayan. Manakala di kawasan hulu sungai yang didiami oleh orang Lun Bawang terlibat dalam aktiviti pertanian.

Ketegangan hubungan Kerajaan Sarawak dengan SBUB ${ }^{2}$ telahpun bermula apabila Kerajaan Sarawak membawa Sungai Baram ke dalam Kerajaan Sarawak. Walau bagaimanapun ketegangan hubungan kedua-dua Kerajaan semakin buruk apabila Kerajaan Sarawak ingin meluaskan jajahan sehingga ke Sungai Trusan. Artikel ini akan membincangkan bagaimanakah persaingan di antara kedua-dua kerajaan dan penglibatan wazir di Brunei dalam isu Sungai Trusan yang berakhir dengan penyerahan Sungai Trusan kepada Kerajaan Sarawak. Walau bagaimanapun ketegangan politik ini semakin berkurangan pada awal abad ke-20 apabila pengambilan Sungai Lawas tidak lagi melibatkan ketegangan bersama SBUB sebaliknya hanya melalui rundingan berdasarkan kepentingan ekonomi kedua-dua pihak melalui pertukaran daerah dan konsesi tanah perlombongan di Teluk Brunei. Apakah masalah di Sungai Lawas yang menyebabkan SBUB menyerahkan kawasan tersebut kepada Kerajaan Sarawak? Bagaimanakah Kerajaan Sarawak menyelesaikan tuntutan para pengiran dan Brooke Johnson bagi memenuhi syarat Kerajaan British bagi membawa Sungai Lawas ke dalam Kerajaan Sarawak? Persoalan-persoalan ini bermula dengan hasrat Raja Brooke ingin meluaskan jajahan negeri Sarawak. Oleh itu perlu dilihat latar belakang usaha Brooke ini.

\section{Sejarah Awal Pembentukan Kerajaan Sarawak}

Kedudukan Negeri Sarawak, Sabah dan Brunei terletak di utara Pulau Borneo dan menghadap Laut China Selatan yang menjadi laluan utama pedagang di antara China, India dan Tanah Arab. Laluan perdagangan ini sangat penting bukan sahaja kepada pedagang tetapi juga kepada Kerajaan British di Singapura dan India. Wilayah Sarawak yang asal (Daerah Kuching) terletak paling jauh daripada pusat pentadbiran Brunei menyebabkan Sarawak hanya ditadbir secara tidak langsung oleh pembesar-pembesar tempatan Sarawak yang terdiri daripada Datu Patinggi, Datu Temenggong, dan Datu Bandar. ${ }^{3}$ Pembesar-pembesar Sarawak ini diberikan kuasa autonomi dalam pentadbiran negeri Sarawak disebabkan Daerah Sarawak tidak memiliki kekayaan hasil bumi. Jumpaan emas dan antimoni telah membuka mata Kerajaan Brunei untuk kembali mengawal pentadbiran Sarawak secara terus daripada Brunei. ${ }^{4}$ Keadaan ini telah 
menimbulkan gangguan dalam struktur kuasa penduduk tempatan yang telah dinikmati untuk suatu jangka masa yang panjang. Keinginan untuk mengambil semula kuasa daripada pembesar tempatan Sarawak dan juga mengawal sumber ekonomi telah menimbulkan tentangan penduduk Sarawak ke atas pemerintahan Putera Mahkota. Tentangan telah menimbulkan huru hara dan ketidakstabilan pentadbiran Brunei di Sarawak. Justeru itu Pengiran Muda Hashim telah dihantar bagi membantu mengamankan Daerah Sarawak. Namun beliau gagal bertindak disebabkan kebencian penduduk Sarawak ke atas Pengiran Mahkota begitu mendalam. Semasa pemberontakan sedang berlangsung James Brooke telah tiba di Sungai Sarawak pada tahun 1839. Semasa kedatangan James Brooke kali yang kedua pada tahun 1841, Pengiran Muda Hashim telah menawarkan James Brooke jawatan sebagai Gabenor di Sarawak (Daerah Kuching) sekiranya berjaya membantu mengamankan pemberontakan penduduk tempatan yang menentang pentadbiran Putera Mahkota Muhamad Salleh.

James Brooke yang berjaya mengamankan Sarawak telah dianugerahkan jawatan Gabenor Sarawak oleh Pengiran Muda Hashim pada 24 November $1841^{5}$ dan disahkan oleh Sultan Brunei pada tahun 1842. James Brooke memulakan pentadbiran Kerajaan Sarawak yang berpusat di Kuching. Sejak tahun 1841 James Brooke telah bertindak meluaskan pemerintahan beliau dengan memerangi orang Melayu dan Iban yang dilabelkan sebagai lanun bagi mempastikan kedudukan politik beliau di Sarawak tidak tergugat. ${ }^{6}$ Untuk tujuan itu James Brooke turut mengheret kapal-kapal Kerajaan British dalam misi beliau di Sarawak dengan alasan bagi melindungi aktiviti perdagangan dan perkapalan British daripada ancaman lanun. Misalnya tindakan beliau di kawasan Paddi, Paku dan Rimbas ${ }^{7}$ bagi memudahkan James Brooke bertindak di Sungai Skrang dan Saribas. Seterusnya James Brooke meluaskan pengaruh dengan mengambil sungai Batang Lupar hingga ke sungai Rejang. Di sesetengah kawasan James Brooke mengekalkan pemimpin tempatan misalnya Daerah Sarikei yang ditadbir oleh Syarif Masyhor. ${ }^{8}$ Manakala pemimpin yang menentang beliau akan diperangi ataupun ditukarkan dengan pihak yang boleh menyokong beliau. Tindakan James Brooke turut memberikan kesan negatif apabila berlakunya tindak balas penduduk tempatan Sarawak bagi menghalau beliau keluar daripada Sarawak. Misalnya peristiwa pakatan orang Melayu menentang Brooke apabila berlaku pemecatan Datu Patinggi Abd. Ghafur. ${ }^{9}$ Begitu juga dengan penentangan masyarakat Iban $^{10}$ dan $\mathrm{Cina}^{11}$ ke atas keluarga Brooke tidak menghalang Kerajaan Sarawak diperluaskan sehingga melepasi Sungai Baram, Sungai Trusan, Sungai Limbang dan Sungai Lawas di utara Sarawak. Tindak balas penduduk di Kuching, Sungai Batang Lupar, Sarikei dan Mukah jelas memperlihatkan cabaran yang terpaksa dihadapi oleh Raja Brooke bagi menstabilkan Kerajaan Sarawak.

\section{Persaingan Raja Brooke dan Syarikat Borneo Utara British (SBUB)}

Perlumbaan untuk merebut Sungai Trusan sangat berkait rapat dengan persaingan di antara Raja Brooke dan SBUB untuk merebut saki baki tanah jajahan Kesultanan Brunei. Raja Brooke bertindak mengambil jajahan Brunei daripada kawasan Sungai Sarawak (Kuching) hingga ke Sungai Baram. Manakala SBUB pula mengambil tanah jajahan di utara Borneo iaitu dari pantai Timur Sabah hingga ke Sungai Padas, Klias, dan Sipitang di pantai Barat. Sehingga tahun 1884 tanah jajahan Brunei yang tinggal hanyalah di Muara Brunei, Sungai Limbang, Sungai Trusan dan Sungai Lawas. Kerajaan Brunei dihimpit oleh kerakusan Raja Brooke dan SBUB yang mahu meluaskan tanah jajahan 
masing-masing.

Idea pembentukan SBUB wujud semasa timbulnya minat daripada beberapa pengusaha Eropah dan Amerika untuk membuka syarikat perladangan di Sabah. Tindak tanduk pengusaha Amerika dan German di utara Borneo sangat merisaukan British khususnya selepas tahun 1870. ${ }^{12}$ Malahan James Brooke membantah penglibatan Amerika di Borneo sejak tahun 1865 disebabkan tidak mahu kehilangan pelaburan di Borneo. ${ }^{13}$ Menjelang bulan september 1880 semasa Overbeck ${ }^{14}$ telah menjual keseluruhan syer sahamnya kepada Alfred Dent, ${ }^{15}$ usaha telah dibuat bagi membentuk satu zon lingkungan pengaruh British di utara Borneo. Usaha ini dibuat tanpa bergantung kepada tindakan Raja Brooke di Sarawak yang lebih dilihat untuk kepentingan peribadi keluarga Brooke. Usaha pembentukan sangat disokong kuat oleh Julian Pauncefote ${ }^{16}$ yang memegang jawatan Pembantu Setiausaha di Kementerian Luar British. Dengan hubungan yang baik bersama Alfred Dent dan Sir Rutherford Alcock ${ }^{17}$ semasa di Hong Kong, Pauncefote menjadi orang yang paling kuat menyokong pembentukan British North Borneo Company ataupun SBUB di utara Borneo melalui memorandum yang dicadangkan. ${ }^{18}$

Bagi mengukuhkan penguasaan British di utara Borneo, Julian Pauncefote telah mencadangkan pemberian Piagam diraja ${ }^{19}$ kepada SBUB. Menurut Pauncefote pemberian status Piagam Diraja jauh lebih berkesan daripada status wilayah Protektorat British. Pemberian status ini telah dibantah oleh Charles Brooke ${ }^{20}$ Bantahan terhadap status Piagam ke atas SBUB ini disebabkan terdapat permainan politik antara W.H. Treacher, ${ }^{21}$ Pauncefote dan Sir Rutherford Alcock bagi mengekang usaha peluasan wilayah oleh keluarga Brooke di utara Borneo. Kesan awal persaingan ini jelas melalui usaha Treacher yang menentang pengambilan Sungai Baram oleh kerajaan Sarawak.

Pertikaian berakhir apabila Lord Salisbur ${ }^{22}$ bersetuju untuk memberikan status Piagam ke atas SBUB dan pada masa yang sama memberi kelulusan cadangan pengambilan Baram oleh Kerajaan Sarawak. Walau bagaimanapun sebelum proses ini selesai parti Konservatif telah kalah dalam pilihan raya di Britain yang menyebabkan proses ini tergendala. ${ }^{23}$ Parti Liberal pada peringkat awal sangat menentang proses penambahan wilayah dalam empayar Britain. Namun sedikit demi sedikit pemahaman tentang persaingan dan kepentingan Britain telah mengubah pendirian Kementerian Luar British, dan SBUB telah berjaya memperoleh status Piagam Diraja pada bulan Ogos $1881^{24}$ dengan syarat mengekalkan hak mutlak British ke atas SBUB. Pada masa yang sama SBUB harus mengekalkan status perdagangan bebas di Borneo Utara. Dengan pemberian status Piagam Diraja maka Kementerian Luar British turut bersetuju untuk mengiktiraf pengambilan Baram namun dengan syarat Sultan Brunei bersetuju dengan terma-terma yang ditetapkan oleh Kerajaan Sarawak. ${ }^{25}$

SBUB berjaya memperolehi status Piagam pada 1 November 1881 manakala Kerajaan Sarawak berjaya mendapatkan Sungai Baram pada tahun 1882. Bagi SBUB sempadan Kerajaan Sarawak seharusnya dihadkan tidak melebihi Sungai Baram namun sebaliknya Charles Brooke bercita-cita ingin membawa masuk Sungai Limbang yang dilihat memiliki kekayaan ke dalam Kerajaan Sarawak. Penglibatan Kerajaan Sarawak di Sungai Trusan bermula dengan keinginan Charles Brooke terhadap Sungai Limbang. Pentadbir Sungai Limbang iaitu Pengiran Temenggung Hashim ${ }^{26}$ bersetuju untuk menyerahkan Sungai Limbang kepada Kerajaan Sarawak. Persetujuan ini mendapat bantahan daripada SBUB. Justeru itulah Charles Brooke sentiasa menentang perluasan 
kuasa SBUB di utara Borneo khususnya di Teluk Brunei. Selain hubungan Kerajaan Sarawak dan SBUB yang tidak mesra, hubungan di antara Pengiran Temenggung Hashim dan Pengiran DiGadong juga menambah buruk situasi di Teluk Brunei. Malah terdapat cubaan oleh Raja Brooke menyokong para pengiran yang di ketepikan oleh SBUB misalnya di Sungai Lawas. Kerajaan Sarawak turut melihat cadangan pemberian status wilayah naungan ke atas Brunei sebagai cara Alcock bagi mengekang pengaruh Brooke di utara Sarawak daripada memasuki wilayah Brunei. Pada masa yang sama kuasa-kuasa Eropah khususnya German dan Perancis mulai meningkatkan pengaruh dan kekuasaan di Afrika dan kepulauan New Gunea. Alasan ini digunakan oleh Alcock bagi memastikan status wilayah naungan diberikan kepada Brunei yang sedang mengalami keadaan huru hara. ${ }^{27}$ Walaupun sebenarnya beliau cuba mengelakkan perkongsian sempadan bersama Sarawak yang dijangka akan menimbulkan lebih banyak krisis bersama SBUB.

Isu pengambilan Sungai Baram dan pemberian status Piagam kepada SBUB membuktikan wujudnya persaingan merebut pengaruh di antara kedua-dua Kerajaan Sarawak dan SBUB. Isu Sungai Baram menjadi titik tolak yang mencetuskan perbalahan dalam usaha Raja Brooke mengambil Sungai Trusan. Persaingan kedua-dua pihak telah mengheret isu Sungai Trusan untuk beberapa tahun sebelum diluluskan oleh Kerajaan British.

\section{Status Tanah di Sungai Trusan dan Lawas}

Secara umumnya kebanyakan tempat di Sungai Trusan dan Sungai Lawas memiliki status "Sungai Tulin". "Sungai Tulin" bermaksud wilayah yang dimiliki oleh Sultan, pengiran (biasanya wazir atau ceretia) dan waris mereka. Segala hasil cukai adalah milik peribadi mereka dan boleh diwarisi kepada keturunan. Justeru itu pemilikan "Sungai Tulin" lebih kepada harta pusaka peribadi dan bukannya dimiliki disebabkan memegang sesuatu jawatan seperti mana "Sungai Kerajaan" dan "Sungai Kuripan." Pemilik berhak menggunakan "Sungai Tulin" mengikut kehendak peribadi mereka akan tetapi seseorang Sultan tetap berhak untuk memberikan apa-apa sahaja titah perintah kepada penduduk di semua kawasan "Sungai Tulin." 28 Di samping itu Sultan ataupun Kerajaan Brunei boleh campur tangan sekiranya berlaku huru hara di kawasan "Sungai Tulin" yang gagal diselesaikan pemilik hak tulin. ${ }^{29}$ Walaupun kawasan Sungai Trusan tidaklah terlalu jauh dari Muara Brunei tetapi disebabkan kawalan wilayah yang begitu lemah maka sebarang krisis agak sukar diselesaikan. Disebabkan status Sungai Lawas yang bebas daripada bidang kuasa Kerajaan Brunei, Kerajaan Sarawak ataupun SBUB maka kes penyeludupan senjata sangat mudah dilakukan. Situasi ini menimbulkan kebimbangan kepada ketiga-tiga kerajaan bagi mengelakkan Sungai Lawas menjadi pusat penyeludupan senjata untuk dibekalkan ke wilayah SBUB ataupun Sarawak. Pemilikan senjata yang diluar kawalan menunjukkan bahawa Kerajaan Brunei tidak berjaya mengekang masalah ini dan ini membawa risiko yang tinggi terhadap keselamatan.

Sungai Trusan merupakan hak tulin kepada Pengiran Temenggung Hashim manakala Sungai Lawas dan Sungai Merapok sebahagian besarnya adalah berstatus "Sungai Tulin" yang dimiliki oleh Pengiran Abu Bakar dan Pengiran Tajudin.

\section{Sungai Trusan}

Pemberontakan di Sungai Trusan berlaku hampir serentak dengan pemberontakan di Sungai Limbang pada tahun 1884. Keadaan di Sungai Trusan begitu tegang akibat 
daripada meletusnya pemberontakan oleh penduduk Murut yang menentang pemerintah Brunei dan juga pergaduhan di antara masyarakat Lun Bawang, peniaga dan orang Bisaya. Punca pemberontakan disebabkan tiga faktor iaitu

a) Kadar cukai yang dikenakan oleh pemerintah Brunei yang sangat tinggi.

b) Kesan pergaduhan di antara peniaga Melayu dan Iban dengan masyarakat Lun Bawang di Kampung Loagan Kelilang. Pergaduhan menyebabkan beberapa orang Lun Bawang mati dibunuh malah wang mereka turut dirompak. ${ }^{30}$

c) Pemberontakan berkaitan dengan tindakan pengiran di Brunei yang membawa penduduk suku Murut untuk bertindak ke atas orang Bisaya yang menentang pemerintah Brunei di Sungai Limbang. Disebabkan rundingan di antara W.H. Treacher bersama penduduk Bisaya telah berjaya maka mereka telah diminta kembali ke Sungai Trusan. Namun terdapat sebahagian daripada tentera upahan Murut yang tidak berpuas hati disebabkan tidak berlaku perang maka mereka telah bertindak ke atas peniaga di Sungai Trusan yang disangka adalah penduduk Bisaya. Tindakan yang dilakukan oleh tentera upahan ini disebabkan mereka tidak mahu balik dengan tangan kosong. ${ }^{31}$ Tindakan mereka menimbulkan ketegangan di Sungai Trusan dan menyebabkan Kerajaan Brunei sukar untuk mengambil tindakan.

Disebabkan keadaan di Sungai Trusan agak tegang, Kerajaan Brunei telah mengeluarkan amaran agar peniaga dari Sarawak yang menjalankan perniagaan dan pengumpulan hasil hutan meninggalkan Brunei. Kerajaan Brunei juga menegah kaum Dayak (Orang Iban dari Sarawak) daripada memasuki kawasan Sungai Trusan dalam perjalanan pulang ke Sungai Baram.

Amaran oleh kerajaan Brunei ini disambut dengan cara yang baik disebabkan hubungan persahabatan di antara orang Dayak dan penduduk setempat yang telah lama terjalin. Justeru itu orang-orang Dayak ini hanya mengambil sedikit sahaja langkah berjaga-jaga disebabkan tidak yakin akan pemberontakan yang besar akan tercetus. ${ }^{32}$ Para peniaga dari Sarawak yang melalui Sungai Trusan dan tidur di bot masing-masing telah diserang hendap menyebabkan 17 orang mati terbunuh. Salah seorang daripada yang terselamat telah berjaya melarikan diri ke Labuan. ${ }^{33}$

Ketegangan di Sungai Trusan berpunca daripada hubungan tidak harmoni di antara penduduk Sungai Trusan dan pemerintah Brunei. Treacher beranggapan peristiwa pembunuhan orang-orang Dayak dilakukan oleh para penentang kerajaan Brunei disebabkan berlaku salah faham terhadap orang yang sedang tidur di dalam bot. Salah faham berpunca daripada orang-orang Dayak di dalam bot tidur menggunakan seluar panjang sama seperti orang Brunei. Ia tidak seperti kebiasaan orang Dayak yang menggunakan cawat. Walau bagaimanapun analisis menunjukkan tindakan pemberontak bukan hanya terhadap orang Iban tetapi juga terhadap orang Melayu. Justeru, sasaran yang dipilih bukanlah tersalah pilih tetapi memang bertujuan membunuh orang Melayu dan Iban dari Sarawak. Selain orang Iban dan Melayu Brunei terdapat juga peniaga berbangsa Melanau turut terbunuh di Sungai Trusan. ${ }^{34}$

Sehubungan dengan insiden pembunuhan rakyat Sarawak di kawasan jajahan Brunei, maka Kerajaan Sarawak telah menghantar F.O. Maxwell bagi menyiasat. ${ }^{35}$ Maxwell telah menghantar protes kepada Sultan dan Pengiran Temenggung Hashim untuk melaksanakan satu siasatan. Akan tetapi Sultan dan Temenggung mengakui bahawa kerajaan Brunei tidak mampu untuk melaksanakan siasatan dan hukuman yang 
sewajarnya disebabkan suasana tegang masih berlaku. Kegagalan pemerintah Brunei menghukum mereka yang terlibat telah menyebabkan Maxwell membuat ugutan untuk menahan bayaran pampasan daripada Kerajaan Sarawak selama dua tahun yang bernilai $\$ 22,000$. Pengiran Temenggung Hashim berusaha untuk mendapatkan pinjaman daripada SBUB bagi membayar denda akan tetapi SBUB enggan memberikan pinjaman wang. ${ }^{36}$ Kegagalan membayar pampasan tersebut menyebabkan Kerajaan Brunei terpaksa menyerahkan Sungai Trusan kepada Kerajaan Sarawak dengan harga \$4500 kepada Pengiran Temenggung Hashim. ${ }^{37}$ Di sini kita dapati Raja Brooke memanipulasi kelemahan kewangan Kerajaan Brunei yang dijadikan senjata bagi memerangkap Kerajaan Brunei dalam isu Sungai Trusan. Gagal membayar pampasan menyebabkan pemerintah Brunei terpaksa menyerahkan Sungai Trusan kepada Sarawak dengan kadar $\$ 4500$ kepada Pengiran Temenggung Hashim. ${ }^{38}$ Menurut Treacher penyerahan Trusan dilakukan setelah Brunei gagal memperoleh pinjaman daripada SBUB bagi membayar pampasan kepada Sarawak. ${ }^{39}$ R. Haller-Trost pula menyifatkan penyerahan Trusan oleh Temenggung Hashim disebabkan ketidakupayaan Brunei mengawal Sungai Trusan dan memperoleh kutipan cukai. ${ }^{40}$ Sebagai langkah tindak balas keenganan SBUB membantu Pengiran Temenggung Hashim maka Sungai Trusan telah diserahkan kepada Kerajaan Sarawak secara rasmi pada 12 Disember $1884^{41}$ Dilihat dari sisi yang lain penyerahan Sungai Trusan berkait dengan keinginan Pengiran Temenggung Hashim menghalang tekanan dari SBUB ke atas Kerajaan Brunei tanpa melihat bahawa keseluruhan Kerajaan Brunei telah dikelilingi oleh Kerajaan Sarawak yang juga turut berminat menghapuskan keseluruhan wilayah Kerajaan Brunei untuk dibawa masuk ke dalam Kerajaan Sarawak. Kejatuhan Sungai Trusan dilihat oleh Treacher sebagai kelemahan utama pendekatan SBUB ke atas Brunei yang menyebabkan Raja Brooke Berjaya mengambil Sungai Trusan. Di samping itu kekurangan sumber kewangan dan kekurangan tenaga tentera SBUB berbanding Kerajaan Sarawak juga merupakan salah satu faktor yang menyebabkan Brooke berjaya di Sungai Trusan. ${ }^{42}$ Brooke dan Kerajaan Sarawak menggunakan kedua-dua sumber ini bagi menarik sokongan Pengiran Temenggung Hashim untuk memihak kepada Raja Brooke. Kejatuhan Sungai Trusan bermakna Kerajaan Sarawak berjaya menyekat penglibatan SBUB untuk bersaing bagi mendapatkan Sungai Limbang yang terletak di selatan Sungai Trusan.

Alcock menggambarkan sikap Rajah Brooke sebagai “...an antagonistic and openly hostile character." ${ }^{33}$ Kebimbangan perkongsian sempadan bersama ini telah mendorong Alcock untuk mendesak Kementerian Luar British agar menolak kelulusan permohonan Kerajaan Sarawak untuk mengambil Sungai Trusan. ${ }^{44}$ Bagi Alcock alasan untuk mengelak campur tangan kuasa Eropah yang lain di kawasan-kawasan bebas di tanah jajahan Brunei tidak dapat diterima disebabkan Kerajaan Brunei telahpun menandatangani perjanjian 1847 dengan Kerajaan British. Malah Alcock turut mencadangkan agar Kerajaan British memberikan status wilayah naungan meliputi seluruh kawasan daripada sungai Baram hingga ke Sungai Padas. Sebenarnya kebimbangan Alcock berdasarkan logik sekiranya Sungai Trusan dapat diambil oleh Raja Brooke maka keseluruhan Kerajaan Brunei hanya menunggu masa untuk dibawa masuk sebagai sebahagian daripada wilayah Sarawak. Idea Alcock inilah juga yang akhirnya membawa kepada Perjanjian 1888 di antara Kerajaan Sarawak, Brunei, SBUB dan British. 
Melalui penyerahan Sungai Trusan, Kerajaan Brunei berasa kedudukan Brunei agak lebih selamat daripada ancaman SBUB yang juga ingin mengambil satu persatu wilayah Brunei dari utara. Pentingnya penyerahan Sungai Trusan daripada perspektif Kerajaan Brunei ialah ianya dapat menyekat tekanan berterusan SBUB ke atas Kerajaan Brunei. Malah yang lebih penting bagi Pengiran Temenggung Hashim perjanjian penyerahan Sungai Trusan dengan Kerajaan Sarawak akan dapat mengukuhkan hubungan Kerajaan Brunei dan Sarawak dan juga dapat melindungi Kerajaan Brunei daripada ancaman SBUB pada masa hadapan. ${ }^{45}$

Kerajaan Brunei juga sedar hubungan kurang baik di antara Kerajaan Sarawak dan SBUB dengan meletakkan kedua-dua kuasa berkongsi sempadan dan pada masa yang sama berharap ketegangan berpanjangan di antara kedua-dua pihak akan dapat mengurangkan tekanan kepada Kerajaan Brunei. Situasi ini secara tidak langsung meletakkan SBUB terpaksa berhadapan dengan Kerajaan Sarawak di utara Borneo. Untuk tempoh seketika Kerajaan Brunei berjaya meletakkan tekanan persaingan bukan hanya kepada Kerajaan Brunei tetapi juga kepada Kerajaan SBUB untuk berkongsi sempadan dengan Kerajaan Sarawak. Kejayaan Sarawak memperoleh Sungai Trusan telah menimbulkan rasa iri hati di pihak SBUB yang telah gagal memperoleh kawasan tersebut daripada Brunei. Justeru itu selepas F.O. Maxwell berjaya memperolehi Sungai Trusan, pihak SBUB melalui W.H Treacher di Labuan telah membantah tindak tanduk Raja Brooke kepada Pejabat Tanah Jajahan di London agar memutuskan sama ada tindakan Kerajaan Sarawak mendapat kelulusan ataupun sebaliknya. Disebalik bantahan ke atas tindakan Brooke di Sungai Trusan, SBUB telah meneruskan tindakan pengambilan Sungai Padas, Klias dan Sungai Kawang pada pertengahan bulan Mac 1885. F.O. Maxwell menuduh SBUB mengambil kesempatan di atas keuzuran Sultan Abdul Momin. ${ }^{46}$ Selain itu Pengiran Temenggung Hashim turut memprotes tindakan Kerajaan Brunei memberikan konsesi untuk melombong arang batu di Muara Besar dan Muara Damit kepada W.C. Cowie. ${ }^{47}$ Bantahan Pengiran Temenggung turut disokong oleh Raja Brooke yang menyelar tindakan Sultan Brunei dan DiGadong bahawa ketika menengah Pengiran Temenggung menyerahkan Sungai Trusan mereka mengambil tindakan yang sama ke atas Muara Besar dan Muara Damit. 
Peta 1. Lokasi Sungai Lawas yang terletak di antara SBUB dan Sungai Trusan, Sarawak.

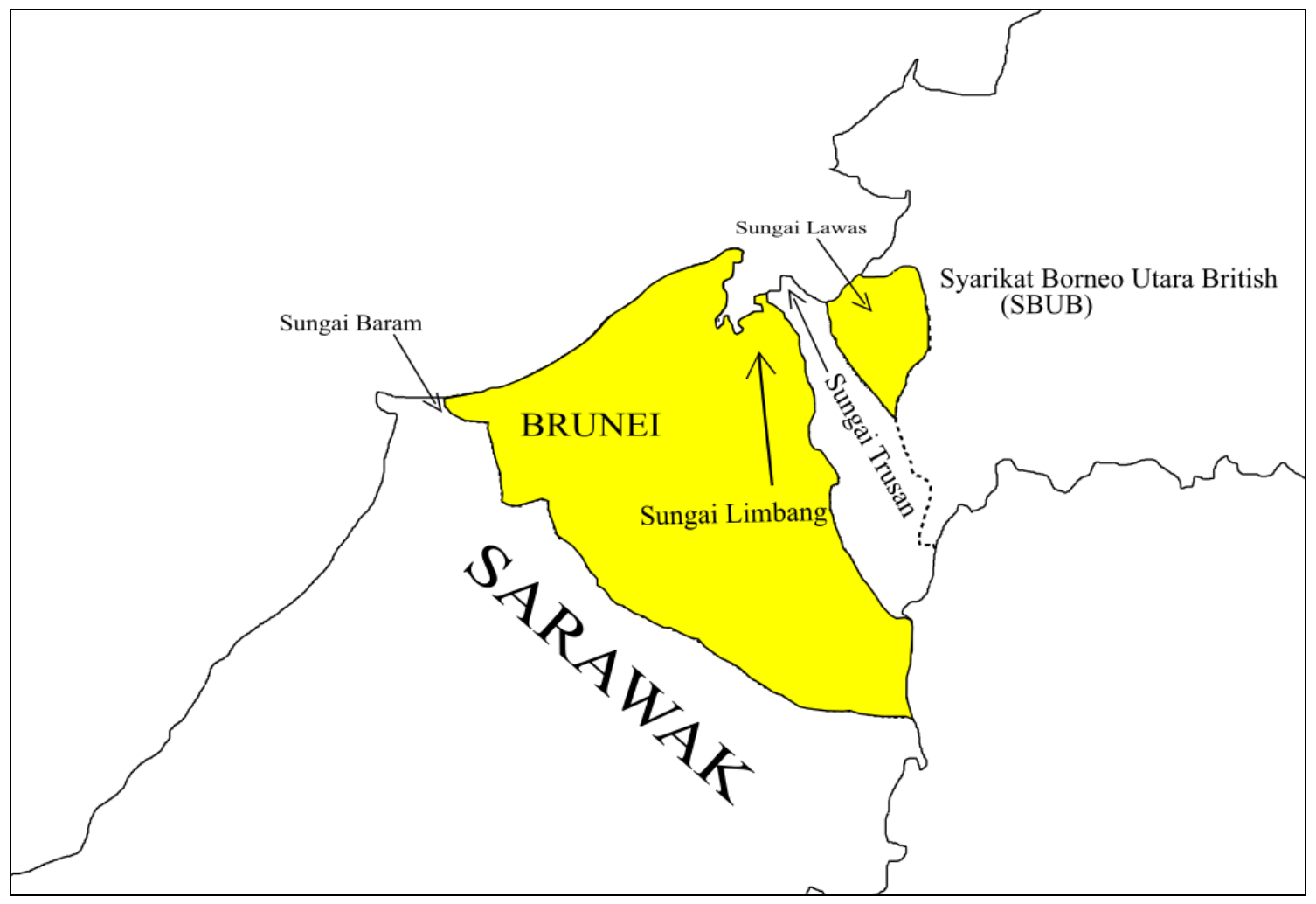

Sumber: FO 572/2, Peta Sarawak, Brunei dan Syarikat Borneo Utara British 1888.

Selepas kenaikan Sultan Hashim menggantikan Sultan Mumin, beliau telah menyerahkan secara rasmi Sungai Trusan pada bulan Januari 1886. Proses pengambilan Sungai Trusan sejak tahun 1884 hingga tahun 1886 menyaksikan banyak konflik kepentingan yang melibatkan pegawai-pegawai SBUB, Sarawak dan wazir di Brunei. Konflik ini telah banyak mengheret Pemangku Konsul-General Labuan (W.H. Treacher) dan pada masa yang sama turut membuat keputusan memihak kepada SBUB. ${ }^{48}$ Walaupun mendapat bantahan daripada SBUB penyerahan Sungai Trusan yang berstatus Sungai Tulin oleh Sultan Hashim (sebelum itu berjawatan Temenggung Hashim) agar sukar disekat disebabkan status Sungai Trusan sebagai sungai tulin malah pemiliknya juga adalah seorang Sultan.

Pengambilan Sungai Trusan penting bagi Kerajaan Sarawak bagi menyekat SBUB daripada meluaskan jajahan takluk di selatan Sungai Trusan. Malah pengambilan Sungai Trusan telah membuka laluan bagi Kerajaan Sarawak untuk bertindak di Sungai Limbang pada tahun 1890 dan memperoleh Sungai Lawas pada tahun 1905.

\section{Pengambilalihan Sungai Lawas}

Sehingga tahun 1901 Sungai Lawas masih sebahagian daripada kawasan yang dimiliki oleh Kerajaan Brunei yang masih bebas daripada penguasaan Kerajaan Sarawak ataupun SBUB. Sungai Lawas sebahagian besarnya adalah berstatus "Sungai Tulin" yang dimiliki oleh Pengiran Abu Bakar dan Pengiran Tajudin. Pengiran Abu Bakar pula memperolehi 
hak Tulin tersebut berdasarkan pemberian oleh Sultan Mumin. Beliau memperoleh hak tersebut selepas berjaya dalam permohonan bagi membuka kawasan baharu yang belum diusahakan dalam jajahan Brunei. Pengiran Abu Bakar telah mengagihkan hak Tulin kepada beberapa orang Pengiran yang terdiri daripada keluarga beliau. Beberapa tempat di Sungai Lawas dimiliki oleh beberapa orang pengiran yang berstatus "Sungai Tulin". Pada bulan 7 September 1901 SBUB telah mengambil hak kerajaan Sungai Lawas daripada Sultan Hashim dengan keizinan daripada Kementerian Luar British secara bersyarat.

all the sovereignty rights and powers, and all other powers and rights and the like which are included in Our powers and rights over and in the districts lying between the River Sipitang and Terusan including the rivers Merintaman, Mengalong, Merapok, Lawas, Sari, Punang, Lumut (Siang Siang), Kabap, Putus, Pelait, Bumbun and Langareh together with all the lands, sea bays, and rivers not herein mentioned lying on the North of Terusan. ${ }^{49}$

Terdapat dua sebab utama yang menyebabkan SBUB bertindak mengambil Sungai Lawas:

a) Sungai Lawas menjadi tempat penyeludupan senjata secara bebas untuk dibekalkan kepada penentang Kerajaan SBUB. ${ }^{50}$

b) Walaupun perdagangan bebas dijalankan di Sungai Lawas namun terdapat bukti pemerdagangan manusia turut dilakukan sebagai hamba abdi yang dilakukan oleh suku kaum di pedalaman Lawas. ${ }^{51}$

Secara umumnya terdapat dua jenis hak yang terdapat di Sungai Lawas iaitu:

a) Sungai Kerajaan ataupun hak kedaulatan yang dimiliki sepenuhnya oleh Sultan Brunei. Hak kedaulatan yang dimiliki oleh Sultan Brunei di Sungai Lawas ialah hak ke atas semua bahan galian yang dilombong di Sungai Lawas dan juga kuasa untuk campur tangan sekiranya berlaku anarki di sungai Tulin.

b) Sungai Tulin berstatus seperti harta pusaka.

Proses pengambilan keseluruhan kawasan di antara Sungai Trusan hingga ke sempadan Sungai Sipitang berjalan dengan baik kecuali yang melibatkan hak di Sungai Lawas yang dimiliki oleh Pengiran Abu Bakar. Masalah timbul apabila Pengiran Abu Bakar dan waris mereka enggan menjualkan hak Tulin beliau ${ }^{52}$ sedangkan kesemua kawasan sekitar Sungai Lawas yang dianggap sebagai kawasan bebas ${ }^{53}$ telah dijual oleh Sultan Brunei kepada SBUB sejak tahun 1901.

Justeru itu tindakan SBUB dan Kerajaan Brunei di Sungai Lawas hanya menyelesaikan hak Kerajaan Brunei ke atas Sungai Lawas. Akan tetapi sebahagian besar pemegang hak Tulin enggan untuk menyerahkan hak Tulin mereka kepada SBUB disebabkan tidak mahu ditadbir oleh pihak SBUB. Keadaan ini menyebabkan sebahagian daripada mereka telah mengambil tindakan berunding dengan Raja Brooke agar Sungai Lawas dapat menjadi sebahagian daripada pentadbiran Kerajaan Sarawak meskipun pada peringkat awal Raja Brooke sendiri kurang berminat untuk terlibat di Lawas. ${ }^{54}$ Manakala terdapat beberapa orang Pengiran yang memiliki hubungan yang baik dengan Raja Brooke bertindak ingin menyerahkan ataupun menjualkan hak tulin mereka kepada Kerajaan Sarawak. 
Ketegangan di Lawas memuncak apabila Gabenor E.W. Birch ${ }^{55}$ telah membawa tentera SBUB ke Lawas dan menakluki Sungai Merapok pada akhir tahun 1902. Ketegangan ini berakhir dengan campur tangan Konsul British di Labuan dan Raja Brooke yang menegah pihak SBUB untuk mengambil hak Tulin Pengiran Abu Bakar secara paksa. Bagi menghadapi tindakan SBUB, pada bulan Jun 1903 Pengiran Abu Bakar telah meminta Brooke Johnson mentadbir Sungai Lawas bagi pihak beliau. Tindakan beliau ini dilihat untuk menyekat SBUB daripada bertindak di Sungai Lawas. Akibatnya SBUB terpaksa berhati-hati untuk bertindak di Sungai Lawas apabila Kerajaan Sarawak dan Konsul British di Labuan turut campur tangan. Pengiran Abu Bakar dilihat sebagai seorang yang bijak bermain politik telah menolak tindakan keras SBUB dengan membuat konsesi bersama Brooke Johnson.

Sebelum meneruskan tindakan di Sungai Lawas, Brooke Johnson telah merujuk status Lawas kepada Konsul British di Labuan pada 13 Julai 1903. Konsul British memaklumkan kepada Brooke Johnson tentang status hak Tulin yang dimiliki oleh Pangiran Abu Bakar sangat luas. ${ }^{56}$ Walau bagaimanapun status hak Kerajaan di Lawas telah dibeli oleh SBUB daripada Kerajaan Brunei. Yakin dengan bidang kuasa dan hak milik Pengiran Abu Bakar maka Brooke Johnson telah membuat satu tinjauan awal tentang keperluan pentadbiran di Sungai Lawas pada bulan Ogos 1903. Berdasarkan pemerhatian beliau di dapati tidak wujud sistem kerajan yang teratur di Sungai Lawas dan untuk tujuan itu beliau memerlukan dana awal sebagai permulaan pentadbiran Sungai Lawas. Brooke Johnson juga memahami tentang aktiviti penyeludupan barangan di Sungai Lawas yang berlaku secara berleluasa. Bagi Brooke Johnson hanya dengan cara memperkenalkan kadar cukai import dan eksport yang sama seperti yang dikenakan oleh Kerajaan Sarawak dan SBUB bagi mengawal isu penyeludupan di Sungai Lawas. ${ }^{57}$ Namun sebelum memulakan tugas beliau telah merujuk isu tersebut kepada Gabenor Negeri-negeri Selat di Singapura pada 28 September 1903 sama ada beliau boleh meneruskan urusan tersebut. Jawapan yang ditunggu beliau hanya sampai pada 5 Oktober 1903 apabila Gabenor Negeri-negeri Selat menasihati Brooke Johnson tentang keperluan untuk memperolehi kebenaran daripada pemilik hak Kerajaan di Sungai Lawas iaitu SBUB. Secara kebetulan pada bulan September 1903 sebelum itu Brooke Johnson semasa berada di Singapura beliau ada berbincang dengan Gabenor Birch di Singapura tentang hasrat untuk mentadbir Lawas bagi pihak Pengiran Abu Bakar. Gabenor Birch secara lisan agak bersetuju sekiranya Brooke Johnson dapat membantu pentadbiran di Sungai Lawas. Namun Gabenor Birch tidak menjelaskan secara terperinci hal ehwal hak Kerajaan dan keperluan-keperluan lain yang perlu dilakukan oleh Brooke Johnson.

Sekembalinya Brooke Johnson dari Singapura pada bulan November 1903, beliau telah bersetuju menandatangani satu perjanjian konsesi bersama dengan Pengiran Abu Bakar untuk mentadbir Sungai Lawas selama 10 tahun dengan syarat: ${ }^{58}$

1. Mendapat kelulusan daripada Kerajaan British, Sarawak dan British North Borneo Company (SBUB).

2. Pengiran Abu Bakar membenarkan beliau (Brooke Johnson) mentadbir sehingga kepada tarikh yang dibenarkan.

3. Memberikan Brooke Johnson hak mentadbir selama 10 tahun dan memperoleh ganjaran $10 \%$ daripada pendapatan Sungai Lawas selain daripada gaji tetap. 
Brooke Johnson memaklumkan kepada Birch tentang perjanjian konsesi tersebut pada 16 November 1903. Secara umumnya Birch tidak membantah penglibatan Brooke Johnson dalam aktiviti perniagaan dan membantu Pengiran Abu Bakar di Sungai Lawas dengan syarat beliau dapat membantu menghentikan aktiviti penyeludupan serbuk bahan api, senjata dan ganja yang berleluasa di Lawas. Birch telah merujuk hal tersebut kepada Pengerusi SBUB di London. Berdasarkan penilaian W.C. Cowie tentang peranan Brooke Johnson di Sungai Lawas dan perjanjian yang dibuat bersama dengan Pengiran Abu Bakar bahawa tindakan Brooke Johnson adalah bertentangan dengan perjanjian penyerahan hak Kerajaan di antara Sultan Brunei dan SBUB. Sekiranya Brooke Johnson ingin meneruskan hasrat tersebut beliau hendaklah bersetuju untuk berkhidmat dengan SBUB dan akan dilantik sebagai Residen Province Clarke. ${ }^{59}$

Menjelang tahun 1904 apabila SBUB masih gagal menyelesaikan isu hak Tulin para pemegang hak Tulin ${ }^{60}$ dari Lawas telah bertindak berjumpa dengan wakil Kerajaan Sarawak dan menyatakan komitmen mereka yang menolak pentadbiran SBUB di Sungai Lawas. Pada bulan Februari 1904 Gueritz telah datang berjumpa Brooke Johnson di Lawas dan beliau turut membawa bersama surat lantikan Brooke Johnson sebagai Residen di Pronvince Clarke pada 17 Februari 1904. ${ }^{61}$ Brooke Johnson sedar tanpa surat tersebut beliau tidak dibenarkan untuk melibatkan diri di Sungai Lawas. Akhirnya Brooke Johnson bersetuju menerima lantikan sebagai Residen Province Clarke semata-mata untuk memperolehi kebenaran bagi menjalankan konsesi di Sungai Lawas. Pada masa yang sama Brooke Johnson mengambil kesempatan untuk memulakan perniagaan secara kecil-kecilan di Sungai Lawas. Walaupun nyata kurang bersetuju dengan tindakan SBUB tetapi bagi mempastikan perniagaan beliau di Sungai Lawas berjalan lancar Brooke Johnson menerima lantikan tersebut dan menjalankan tugas sebagai Residen Province Clarke. Selain menjalankan tugas Residen beliau menggunakan peluang tersebut bagi menjalankan tugas sebagai pentadbir di Sungai Lawas. Usaha Brooke Johnson membuahkan hasil apabila berjaya mendapat keyakinan daripada beberapa peniaga dan pelabur Cina yang berminat untuk memulakan aktiviti perladangan di Lawas.

Dengan sokongan pemegang hak Tulin di Sungai Lawas, Raja Brooke cuba memperolehi hak kerajaan di Sungai Lawas daripada pihak SBUB. Beliau sangat yakin akan berjaya disebabkan SBUB sendiripun telah gagal dalam usaha memperolehi sokongan daripada para pengiran di Lawas. Keadaan mula menjadi sukar apabila pada bulan Mac 1904, Pengiran Abu Bakar telah meninggal dunia. Keadaan ini bukan sahaja menimbulkan masalah kepada Kerajaan Sarawak tetapi juga kepada Brooke Johnson yang menandatangani perjanjian konsesi bersama Pengiran Abu Bakar. Masalah menjadi semakin rumit disebabkan Pengiran Abu Bakar memiliki 18 orang waris yang terdiri daripada isteri dan anak-anak beliau.

Selepas pertengahan tahun 1904 SBUB menggesa Brooke Johnson mengurangkan penglibatan di Sungai Lawas. Namun Brooke Johnson membantah disebabkan persetujuan penglibatan bersama SBUB adalah bagi membolehkan beliau terlibat dalam perniagaan di Sungai Lawas. Akibat beban kerja yang banyak Brooke Johnson telah menghantar surat perletakan jawatan pada bulan Ogos 1904. Ini disebabkan beliau tidak dapat memberikan komitmen sepenuhnya di Sungai Lawas. Namun beliau dapat dipujuk oleh Guetriz agar kembali untuk menjalankan tugas bersama SBUB.

Hanya menjelang bulan November 1904 barulah Brooke Johnson mendengar secara rasmi tentang hasrat SBUB ingin menjual hak Kerajaan yang diperolehi daripada 
Sultan Brunei kepada Kerajaan Sarawak. Tindakan ini dilakukan apabila wakil penduduk Lawas berulang kali menegaskan hanya akan bersedia untuk menerima pentadbiran Kerajaan Sarawak dan bukannya SBUB. SBUB sedar penolakan penduduk tidak memberikan pilihan yang menguntungkan buat SBUB. Sekiranya penduduk Sungai Lawas dipaksa menerima pentadbiran SBUB dan berlaku pemberontakan maka kos yang ditanggung akan menyebabkan pemegang-pemegang saham SBUB akan menanggung kerugian yang besar. Selain faktor di atas terdapat sebab lain yang menghalang waris Pengiran Abu Bakar menjual hak Tulin beliau kepada SBUB iaitu faktor hubungan di antara Pengiran Abu Bakar dengan Raja Brooke yang begitu rapat. Kedua-dua faktor ini telah membawa SBUB ke meja rundingan penyerahan hak di Sungai Lawas kepada Kerajaan Sarawak. Pihak SBUB bersetuju menyerahkan hak kedaulatan di Sungai Lawas dan sebagai gantinya Kerajaan Sarawak akan membayar sebanyak $£ 5000$ dan menyerahkan beberapa kawasan perlombongan di Teluk Brunei yang terletak berhampiran dengan Daerah Weston kepada SBUB. ${ }^{62}$

Kerajaan Sarawak dan SBUB telah menandatangani perjanjian pengambilan Sungai Lawas pada 12 Januari 1905. Dengan menandatangani perjanjian pengambilan dan pertukaran daerah ia telah mengubah corak persaingan semasa Raja Brooke mengambil Sungai Trusan pada tahun 1884. Kemasukan Lawas dalam negeri Sarawak diumumkan oleh Raja Muda pada 16 Januari 1905. Notis penyerahan telah dibaca oleh wakil SBUB:

Now therefore I, Edward Peregrine Gueritz, the Company Principal Representative in Borneo, do hereby assign and cede to His Highness the Rajah of Sarawak all sovereign and "tulin" rights in the said districts, and call upon all chiefs, headmen, and other inhabitants to render true and loyal allegiance to the Government of His Highness the Rajah of Sarawak. ${ }^{63}$

Bagi E. L. Leonard dan P. W. Stevens tujuan penyerahan Daerah Lawas ini oleh SBUB kepada Kerajaan Sarawak ialah semata-mata untuk memperbaiki hubungan dua hala kedua-dua kerajaan. ${ }^{64}$ Justeru itu tidak hairanlah ia berlangsung dengan cara yang begitu mudah. Walau bagaimanapun masih terdapat bantahan daripada para pengiran yang menjadi penguasa dan pentadbir di Sungai Lawas. Bantahan terhadap pengambilan hak para pengiran disampaikan kepada Charles Brooke semasa lawatan beliau pada 29 April 1905 ke Brunei. ${ }^{65}$ Satu perbincangan telah diatur oleh Sultan Brunei dan para pengiran bersama-sama Charles Brooke bagi menyelesaikan isu Lawas pada 1 Mei 1905. ${ }^{66}$ Kegagalan menyelesaikan isu hak tulin telah membawa pemegang hak tulin menghantar surat memohon perlindungan daripada Kerajaan British terhadap hak mereka. Campur tangan Kerajaan British telah membawa Kerajaan Sarawak dan pemegang hak Tulin ke meja rundingan bagi menyelesaikan isu hak tulin. Terdapat dua masalah utama di Sungai Lawas iaitu perjanjian hak Tulin dengan Brooke Johnson dan yang kedua hak pemegang Tulin yang menjadi waris kepada Pengiran Abu Bakar

Dengan berkuat kuasanya penyerahan hak Kerajaan ini Brooke Johnson telah dipecat daripada SBUB pada 15 Disember 1904. Namun pemecatan ini tidaklah menimbulkan masalah kepada Brooke Johnson akan tetapi pembelian hak Kerajaan di Sungai Lawas oleh Kerajaan Sarawak daripada SBUB mulai menimbulkan masalah 
kepada beliau. Peralihan ini menyebabkan ketidakpastian tentang status perjanjian yang dipersetujui di antara beliau bersama dengan Pengiran Abu Bakar. Pengiran Abu Bakar telahpun meninggal dunia manakala hak Kerajaan telah beralih daripada SBUB kepada Kerajaan Sarawak. Brooke Johnson sendiri tidak memiliki sebarang hubungan dengan Kerajaan Sarawak tidak seperti mana lantikan ke jawatan Residen Province Clarke oleh SBUB. Pada 22 Januari 1905 semasa lawatan rasmi Raja Muda ke Sungai Lawas, beliau memaklumkan tentang arahan daripada Raja Brooke agar Brooke Johnson harus keluar daripada Daerah Lawas bersama dengan semua harta yang dimiliki.

Raja Brooke sangat marah dengan tindakan Brooke Johnson dan tidak mengiktiraf tindakan beliau di Lawas. Bagi Raja Brooke penduduk Sungai Lawas telahpun bersetuju untuk bersama dalam Kerajaan Sarawak dan isu hak Tulin mereka akan dibincangkan bersama para pengiran yang terlibat. Berkaitan dengan perjanjian konsesi Brooke Johnson, Raja Brooke menegaskan bahawa beliau tidak akan membayar sebarang wang pampasan. Brooke Johnson yang kecewa dengan pendirian Raja Brooke cuba mempertahankan tindakan beliau bahawa ia diambil untuk mempertahankan hak para pengiran daripada diambil oleh SBUB pada tahun 1903. Bagi Brooke Johnson tindakan beliau di Sungai Lawas hanyalah menjalankan urusan bersama pemegang hak Tulis berdasarkan perjanjian konsesi yang dipersetujui.

Raja Brooke turut mempersoalkan perjanjian yang ditandatangani di antara Brooke Johnson dan para Pengiran di Sungai Lawas adalah tidak sah. Bagi Raja Brooke perjanjian yang dibuat tidak lengkap disebabkan pengambilan hak Tulin haruslah bersama dengan hak kedaulatan. Akan tetapi semasa membuat perjanjian hanya hak Tulin yang disebut dan mengenepikan pemilik hak kedaulatan. Brooke Johnson mempertahankan tindakan beliau telahpun mendapat kebenaran daripada pemilik hak Kerajaan sebelum itu iaitu SBUB;

\section{It seems almost necessary to inform you that I have permission from North Borneo Company to work for these Pangerans (Chiefs) in Lawas. ${ }^{67}$}

Walaupun Johnson menyatakan bahawa tindakan beliau telah dipersetujui oleh SBUB tetapi pihak SBUB telah menafikan pernah memberikan kebenaran kepada Johnson pada 6 Januari 1904. Pengakuan daripada SBUB bagi Raja Brooke jelas menunjukkan keseluruhan tindakan Johnson di Lawas adalah salah dan bertentangan dengan peraturan sedia. Maka atas sebab itulah Raja Brooke berkeras tidak mahu menghormati perjanjian Brooke Johnson bersama dengan para Pengiran di Sungai Lawas. Bagi Raja Brooke sekiranya SBUB pernah mengeluarkan persetujuan untuk Brooke Johnson menjalankan aktiviti di Sungai Lawas tetapi ia adalah bersyarat iaitu dengan syarat bersetuju berkhidmat dengan SBUB sebagai Residen Province Clarke ${ }^{68}$ pada 17 Februari 1904. Maka apabila SBUB menyerahkan keseluruhan hak Kerajaan kepada Sarawak maka secara automatik ia menghapuskan hak Brooke Johnson dalam perjanjian di Sungai Lawas.

Pandangan Johnson ini bagi Raja Brooke adalah tidak benar disebabkan sekiranya beliau membantu memberikan nasihat bagi mengelakkan hak Tulin para pengiran dirampas beliau mempersoalkan tindakan beberapa orang Pengiran dari Lawas yang datang berjumpa dengan beliau di Kuching bagi menyatakan pendirian untuk menyokong 
kemasukan Sungai Lawas bersama Kerajaan Sarawak. Raja Brooke berpandangan bahawa sikap dan tindakan Brooke Johnson di Lawas lebih banyak untuk menghasut pembesar dan penduduk di Sungai Lawas agar menolak daripada bersama Kerajaan Sarawak.

Bagi Brooke Johnson sekiranya beliau perlu keluar maka pampasan perlu dibayar sebagai ganti rugi. Raja Muda Sarawak datang bagi membeli hak Tulin daripada para waris di Sungai Lawas namun beliau juga terpaksa berhadapan dengan penolakan daripada sebahagian besar waris. ${ }^{69}$

Pada 15 Februari 1905, Brooke Johnson turut menerima surat daripada peguambela beliau di London menyatakan bahawa kes beliau di Sungai Lawas memiliki asas dalam perundangan dan menasihati Brooke Johnson agar meneruskan kerja berdasarkan perjanjian konsesi melainkan dalam keadaan yang terpaksa ataupun dibayar pampasan yang bersesuaian. Malah peguam beliau meyakinkan Brooke Johnson sekiranya beliau dilayan secara tidak adil maka mereka akan membuat rayuan di Pejabat Tanah Jajahan di London dan bukannya di Mahkamah. ${ }^{70}$ Bagi Brooke Johnson bayaran pampasan harus dibayar kepada beliau disebabkan beliau telah berusaha selama lebih daripada setahun untuk membangunkan Sungai Lawas. Malah menurut Brooke Johnson SBUB hanya membayar hak Kerajaan kepada Sultan dengan harga yang murah tetapi selepas beliau berusaha di Sungai Lawas harga penyelesaian dengan Kerajaan Sarawak telah meningkat kepada $£ 5000$ iaitu meningkat beberapa kali ganda. Bagi beliau sebahagian dari nilai di Sungai Lawas terdapat sumbangan yang beliau berikan.

Semasa hendak kembali ke Sarawak dari Singapura pada 14 Mac 1905 Brooke Johnson telah menerima surat daripada Raja Brooke yang menghalang beliau untuk kembali ke Sungai Lawas atau mana-mana bahagian di Sarawak. Brooke Johnson yang merasa tidak puas hati dengan tindakan Raja Brooke telah menghantar satu surat protes kepada Kerajaan Sarawak tentang kerugian yang ditanggung beliau di Lawas. ${ }^{71}$ Beliau juga turut merujuk kes tersebut kepada Pesuruhjaya Tinggi British di Singapura untuk mendapat pertimbangan daripada Kerajaan British. Brooke Johnson turut menafikan tuduhan bahawa beliau menghasut penduduk Lawas daripada menjual hak Tulin mereka. Brooke Johnson turut memohon daripada Pesuruhjaya Tinggi British agar memberikan kebenaran dan menjamin keselamatan beliau di Sungai Lawas. ${ }^{72}$ Brooke Johnson turut memohon campur tangan Kerajaan British dan Pejabat Tanah Jajahan bagi membantu menyelesaikan tuntutan beliau terhadap Kerajaan Sarawak di Sungai Lawas. Apabila Brooke Johnson berjaya masuk semula ke Sungai Lawas pada 29 Mac 1905 beliau mendapati suasana di Sungai Lawas agak sedikit tegang apabila wakil Kerajaan Sarawak mula menguatkuasakan peraturan di Sungai Lawas. Pemilik hak Tulin yang enggan menggantung bendera Kerajaan Sarawak telah cuba menggantung bendera Pengiran di Pejabat Pentabir Lawas menyebabkan Cox, Residen Trusan membawa tentera Sarawak untuk bertindak ke atas penduduk Lawas yang enggan mematuhi arahan. Ketegangan memuncak apabila Cox mengarahkan tentera untuk menembak sesiapa sahaja yang menggantung bendera Pengiran di Pejabat Pentadbiran Lawas. Selain itu beliau turut mengarahkan agar semua senjata polis pengiran dirampas. Ketegangan berakhir apabila Cox membenarkan mereka menggantung bendera di kampung masing-masing dan bukannya di Pejabat Pentadbiran Lawas. ${ }^{73}$

Pada 24 April 1905, Raja Brooke datang bersama dengan tentera Sarawak ke Sungai Lawas dan mengumumkan secara rasmi pelantikan Cox sebagai pegawai 
pentadbir di Lawas. Raja Brooke turut memaklumkan kepada semua Pengiran bahawa mulai 24 April 1905 semua jenis kutipan cukai akan dilaksanakan oleh Cox selaku pegawai rasmi Kerajaan Sarawak. ${ }^{74}$ Semua pemegang hak Tulin juga diminta untuk datang ke Brunei bagi merundingkan status hak Tulin masing-masing untuk diselesaikan. Manakala pusat pentadbiran Lawas yang baharu akan dipindahkan ke tempat lain. Ketika berjumpa dengan para Pengiran pada malam tersebut, Brooke Johnson dimaklumkan bahawa sekiranya mereka diminta memberikan pandangan mereka akan mendiamkan diri sehingga wakil Kerajaan British datang untuk memberikan bantuan atau nasihat.

Brooke Johnson turut memohon agar Kerajaan British dapat membentuk satu badan bagi menyiasat tuntutan beliau di Sungai Lawas. Tambahan pula sejak rayuan beliau bersama dengan pemilik hak Tulin pada bulan Mac 1905 semua keputusan dan tindakan di Sungai Lawas telah diarahkan untuk dihentikan buat sementara sehingga keputusan seterusnya dibuat oleh Secretary of State for Foreign Affairs di London.

Isu Sungai Lawas menjadi agak sukar disebabkan oleh tuntutan tiga pihak yang berkepentingan iaitu Kerajaan Sarawak selaku pemegang hak Kerajaan, 18 orang waris pemegang hak tulin, dan Brooke Johnson selaku pemegang konsesi bersama Pengiran Abu Bakar. Brooke Johnson turut mengemukakan hak disebabkan beliau mengalami kerugian sekiranya Kerajaan Sarawak mengambil alih keseluruhan hak Tulin di Sungai Lawas. Bagi mempertahankan hak Kerajaan Sarawak, Raja Brooke enggan mengiktiraf Brooke Johnson dan cuba mengenepikan sebarang tuntutan oleh Johnson dengan mengemukakan tafsiran hak Tulin berdasarkan tafsiran Sultan Hashim. ${ }^{75}$ Dengan sikap pemegang hak Tulin yang bertegas tidak menjualkan hak Tulin cuba mempertahankan hak masing-masing maka krisis di Sungai terus berpanjangan.

Bantahan berterusan oleh para pengiran menyebabkan Kerajaan British menjalankan satu siasatan yang diketuai oleh Henry Conway Belfield. ${ }^{76}$ Siasatan bertumpu kepada status hak "Tulin" para pengiran yang dipertikaikan. Bantahan oleh waris Pengiran Abu Bakar disebabkan beliau yang kehilangan punca pendapatan dan status sebagai penguasa di Lawas. ${ }^{77}$ Selain bantahan daripada para pengiran, Charles Brooke turut berdepan dengan bantahan daripada anak saudara beliau iaitu Brooke Johnson. $^{78}$ Siasatan bermula pada 23 Mei 1905 dengan memanggil semua pengiran yang terlibat bersama Raja Brooke. Perbincangan secara rasmi bermula pada 24 Mei 1905 di Court House, Labuan. ${ }^{79}$ Dalam perbincangan ini pengiran yang hadir terdiri daripada Pengiran Mat Hashim, Pengiran Haji Ismail dan Pengiran Abdul Rahman. Pengiran Muda Mat Hussein pula tidak menghadiri perbincangan tersebut. Manakala Raja Brooke turut disertai oleh C. A. Bampfylde yang berperanan sebagai penasihat beliau. ${ }^{80}$ Melalui perbincangan ini para pengiran menyatakan kesediaan mereka untuk mencari jalan penyelesaian bagi menyelesaikan tuntutan mereka. Raja Brooke cuba untuk mempercepat proses rundingan dengan mengemukakan surat persetujuan yang telah ditandatangani oleh dua daripada tiga orang pengiran yang hadir. Surat tersebut diperolehi oleh Raja Brooke semasa perbincangan di Kuching pada 26 Oktober 1904. Namun H. C. Belfield yang menjadi wakil Kerajaan British telah menolak perakuan dalam bentuk surat penyelesaian. Ini disebabkan beliau mahu mengesahkan bahawa persetujuan para pengiran turut direstui oleh para pengiran yang lain dan ahli keluarga mereka yang turut memiliki kepentingan di Sungai Lawas. Sikap H. C. Belfield telah menimbulkan kemarahan Raja Brooke disebabkan bagi beliau tindakan ini sengaja untuk memanjangkan isu. Walau bagaimanapun para pengiran turut memohon diberikan masa 
untuk berbincang dengan pengikut masing-masing di Lawas. Sebelum menamatkan sesi pada hari tersebut $\mathrm{H}$. C. Belfield melihat terdapat keperluan untuk beliau meneliti bukti bertulis tentang nilai hak Tulin yang sebenarnya. Walau bagaimanapun disebabkan para Pengiran tidak memiliki rekod tersebut mereka mencadangkan agar dirujuk catatan yang disimpan oleh Brooke Johnson berkenaan rekod tahun 1904. Para Pengiran turut menerangkan tentang perjanjian konsesi yang dilakukan oleh Pengiran Abu Bakar dan Brooke Johnson pada tahun 1903. Mereka turut menyatakan kebimbangan sekiranya hak Tulin diserahkan kepada Raja Brooke sedangkan perjanjian di antara Brooke Johnson dan Pengiran Abu Bakar masih berjalan untuk tempoh lapan tahun akan datang. ${ }^{81}$ Gabenor Labuan menyatakan bahawa Kerajaan British tidak akan campur tangan dalam isu di antara Brooke Johnson dan Raja Brooke. H. C. Belfield seterusnya telah menangguhkan prosiding dan bersambung pada 26 Mei 1905.

Prosiding disambung semula pada 26 Mei 1904 di kampung para Pengiran di Kuala Lawas. Sebelum sesi dimulakan H. C. Belfield mengarahkan agar Brooke Johnson dapat berjumpa dengan beliau secara peribadi. Tujuan Gabenor adalah untuk memaklumkan bahawa Kerajaan British tidak berniat untuk campur tangan dalam isu tuntutan beliau di Sungai Lawas. Selain itu Gabenor turut ingin mendapatkan kepastian sejauhmana beliau telah mempengaruhi pendirian para Pengiran untuk tidak menjualkan hak Tulin mereka. Menurut Brooke Johnson beliau tidak pernah menghalang tetapi memujuk agar para Pengiran bersetuju dengan permintaan Raja Brooke. Beliau turut menyatakan tidak akan meminta sebarang gantirugi daripada para Pengiran walaupun sedar berhadapan dengan isu perundangan dalam tuntutan beliau dengan Raja Brooke. Beliau turut menjelaskan persetujuan di antara beliau dan Pengiran Abu Bakar yang membawa kepada perjanjian konsesi. Walaupun menyedari status hak Kerajaan telahpun diserahkan oleh Kerajaan Brunei kepada pihak SBUB tetapi beliau tetap meneruskan pelaksanaan perjanjian konsesi tersebut. Brooke Johnson mengemukakan kos yang ditanggung oleh beliau di Sungai Lawas bagi memulakan pentadbiran kerajaan di sungai Lawas. Kerugian dipihak Brooke Johnson adalah dalam bentuk pelaburan awal yang menggunakan wang peribadi beliau bagi mentadbir Sungai Lawas selepas perjanjian dengan Pengiran Abu Bakar.

Seterusnya H. C. Belfield dalam sesi bersama para pengiran dan wakil mereka tanpa wakil Kerajaan Sarawak bersama telah berpuas hati dengan sikap dan pandangan oleh keseluruhan para pengiran yang nampaknya lebih bersedia dan memahami kehendak Kerajaan Sarawak di Lawas. H. C. Belfield turut menerangkan perlunya keputusan penjualan hak Tulin diputuskan oleh pemegang yang terdiri daripada para Pengiran dan bukannya dibuat secara paksa. Beliau turut memberikan mereka masa untuk berfikir dan berakhir dengan persetujuan untuk menjual hak Tulin mereka kepada Raja Brooke.

Proses seterusnya yang berlangsung adalah melibatkan rundingan harga di antara wakil pemegang hak Tulin dan Kerajaan Sarawak. Rundingan awal di antara kedua-dua pihak menghadapi masalah disebabkan tawaran harga yang dibuat oleh pemilik hak Tulin yang terlalu tinggi. Manakala Raja Brooke pula menawarkan harga pembelian yang terlalu rendah. H. C. Belfield selaku wakil Kerajaan British mahukan agar keputusan yang dicapai oleh kedua-dua pihak diterima secara sebulat suara. Walau bagaimanapun selepas akhir proses tawar menawar didapati perbezaan harga di antara kedua-dua pihak masih lagi mencapai angka ribuan dollar. Gagal mencapai kata putus kedua-dua pihak akhirnya menyerahkan kepada H. C. Belfield untuk membuat keputusan. Keputusan yang 
dibuat oleh beliau merupakan jalan penyelesaian oleh Kerajaan British berkenaan dengan isu hak Tulin. Keputusan akhir oleh H. C. Belfield dibuat berdasarkan rekod pentadbiran Sungai Lawas yang dmiliki oleh Brooke Johnson iaitu Kerajaan Sarawak harus membayar sebanyak $\$ 6,000$ setahun kepada para Pengiran berdasarkan kutipan hasil sebanyak $\$ 6,500$ di Sungai Lawas. Walaupun pembayaran tahunan lebih rendah tetapi menurut Gabenor para Pengiran patut mempertimbangkan kos yang akan dgunakan bagi pentadbiran Sungai Lawas. Selain daripada pembayaran tahunan Raja Brooke turut bersetuju dengan pembayaran ganti rugi kepada Pengiran melalui pembinaan Pusat Pentadbiran Lawas berserta dengan kos tanah dan perabot yang sedia ada. Keputusan ini telah dipersetujui oleh wakil kedua-dua pihak tertakluk dengan kelulusan Kerajaan British berdasarkan laporan yang dibuat oleh H. C. Belfield. Pada akhir prosiding didapati kedua-dua pihak sangat berpuas hati dengan keputusan yang dicapai. Pembayaran akan mula dibayar dalam bentuk ansuran bermula pada 1 April $1905 .^{82}$ Selepas memuktamadkan tawaran harga Charles Brooke berikrar akan menjaga kebajikan penduduk Lawas dan mengekalkan keamanan di sungai tersebut. Status penduduk Lawas adalah sama seperti penduduk Sarawak di daerah-daerah yang lain. Kerajaan Sarawak juga memberi jaminan untuk mengekalkan sistem perdagangan bebas sedia ada di antara Daerah Lawas dan kawasan-kawasan yang lain. ${ }^{83}$

Melalui pemerolehan hak ke atas Sungai Lawas, sebuah pusat pentadbiran yang baharu telah didirikan 14 batu daripada muara sungai Lawas. Dalam masa yang singkat banyak kedai-kedai masyarakat Cina telahpun mula beroperasi. ${ }^{84}$ Pekan Lawas ini dihuni oleh masyarakat Melayu Brunei yang tinggal berhampiran sungai, manakala orang Murut pula tinggal di hulu sungai. Selain itu terdapat juga orang Kedayan yang turut menghuni beberapa sungai-sungai kecil di Lawas. Selari dengan perubahan Sungai Lawas J.F.M Bingley telah menggantikan E.A.W. Cox sebagai Penguasa di Sungai Lawas dan Trusan. ${ }^{85}$

Brooke Johnson yang tidak berpuas hati dengan tindakan Kerajaan Sarawak dan SBUB bertindak menulis di surat khabar Singapore Free Press pada 11 Julai 1905. Brooke Johnson menyatakan Raja Brooke telah bertindak membuang beliau daripada keahlian Sarawak Club dan menegah beliau daripada memijakkan kaki di mana-mana kawasan di Sarawak selepas perjanjian bersama para pengiran di tandatangani. ${ }^{86}$ Menurut pengisytiharan Raja Brooke melalui akhbar Times isu Lawas telahpun selesai dan Brooke Johnson tidak lagi memiliki sebarang hak. Walau bagaimanapun Brooke Johnson membantah dan menegaskan bahawa para pengiran di Sungai Lawas dipaksa menerima perjanjian untuk melepaskan hak Tulin yang tidak dipersetujui sebulat suara. ${ }^{87}$

Kecewa dengan tindakan Raja Brooke dan SBUB, Brooke Johnson telah membuat rayuan kepada Setiausaha di Kementerian Luar British pada Januari 1906. Tuntutan ini dibuat ekoran tindakan beliau telah telah kehilangan kedudukan di Lawas tanpa pampasan. ${ }^{88}$ Beliau mengharapkan melalui campur tangan Kementerian Luar British, hak beliau di Sungai Lawas dapat dikembalikan. Beliau turut menyatakan bahawa telah mengalami banyak kerugian akibat daripada tindakan Kerajaan British di Lawas. ${ }^{89}$ Justeru itu Johnson Brooke telah mengemukakan kes beliau kepada Kerajaan British di London. $^{90}$

Berdasarkan aduan Johnson, Setiausaha Kerajaan British memaklumkan kepada Raja Brooke bahawa adalah sukar untuk menyatakan tindakan Johnson sah atau tidak disebabkan batasan hak bagi pemegang Tulin adalah berbeza bagi setiap daerah di tanah 
jajahan Brunei. Walaupun para pengiran berhak memajakkan hak tetapi mereka turut tertakluk kepada semua perjanjian di antara Kerajaan British dan Kerajaan Brunei. Sekiranya surat SBUB kepada Johnson bertarikh 17 Februari 1904 dijadikan rujukan bagi menahan tindakan Johnson di Sungai Lawas, surat tersebut juga dikatakan tidak explisit. Disebabkan wujud perbezaan dan batasan pemilikan hak Tulin maka status hak Tulin di Lawas menjadi tidak jelas. Walau bagaimanapun Setiausaha Kerajaan Kerajaan British berpendapat Brooke Johnson wajar diberi pampasan bagi hak-hak beliau yang telah diambil akibat pernyerahan hak kedaulatan daripada SBUB kepada Kerajaan Sarawak. ${ }^{91}$ Pampasan yang dicadangkan adalah $£ 1,600$ untuk pembatalan perjanjian bersama pengiran di Lawas dan $£ 120$ untuk nilai rumah kediaman Johnson di Lawas. Pinjaman wang yang diberikan kepada peniaga Cina tidak disentuh secara jelas. Kerajaan Sarawak telah membayar sebanyak £1,720 kepada Johnson melalui Kementerian Luar British pada 24 Mac 1906. ${ }^{92}$

Walaupun pembayaran telah dibuat tetapi kes Johnson tetap berterusan apabila beliau mengadu bahawa pembayaran yang dibuat tidak mengambil kira kerugian lain seperti berikut: ${ }^{93}$

1. Nilai hartanah rumah

$\$ 2,100.00$

2. Pinjaman kepada pentadbiran Lawas $\$ 350.00$

3. Pinjaman kepada peniaga Cina $\$ 5,650.00$

4. Bayaran hasil pendapatan bulan April dan Mei $\$ 400.00$

Pejabat Kementerian Luar menjelaskan bahawa hanya pembayaran $£ 1,720$ yang dipersetujui dan tidak meliputi tuntutan tambahan oleh Brooke Johnson. ${ }^{94}$ Walau bagaimanapun tidak ada keputusan dibuat berkenaan tuntutan yang lain yang dianggap telah ditolak oleh Kementerian Luar akibat daripada beberapa hutang tertunggak yang belum dikutip. Walau bagaimanapun masalah Lawas selesai apabila tamatnya Konsesi yang diberikan kepada Brooke Johnson beberapa tahun kemudiannya. Pada akhir tahun 1906 Kerajaan Sarawak mula merekodkan hasil perdagangan di Sungai Lawas. Hasil import dan eksport di sungai tersebut mulai mencecah hasil sebanyak \$7,572 dan $\$ 6,915 .{ }^{95}$ Secara keseluruhannya proses pengambilalihan Sungai Lawas agak berbeza dengan sungai-sungai lain di Sarawak. Sekiranya pengambilan Sungai Trusan menimbulkan ketegangan di antara Kerajaan Sarawak dan SBUB malah telah mengheret Pejabat Tanah Jajajahan di London dalam membuat keputusan. Akan tetapi Sungai Lawas hanya mengheret pemilik hak Tulin dan Brooke Johnson yang kehilangan pelaburan beliau di Sungai Lawas. Pengambilan Sungai Lawas merupakan proses akhir yang telah melengkapkan struktur daerah di negeri Sarawak dan kekal membentuk pentadbiran Kerajaan Negeri Sarawak pada hari ini. Dengan jatuhnya Sungai Lawas maka berakhirlah pentadbiran tradisional pembesar tempatan dan para Pengiran di seluruh jajahan Brunei di Sarawak. Garisan sempadan rasmi di antara Sarawak dan Sabah secara rasmi mula di lakukan pada 28 Julai 1910 yang kekal menjadi garis pemisah di antara kedua-dua negeri Sarawak dan Sabah. ${ }^{96}$

\section{Kesimpulan}

Melalui pembesaran Kerajaan Sarawak, jelas menunjukkan Charles Brooke tidak begitu mengutamakan penambahan kekayaan negeri Sarawak tetapi beliau lebih cenderung 
kepada sikap imperialis iaitu untuk meluaskan jajahan Sarawak. Pengambilan Sungai Trusan dan Sungai Lawas telah berjaya mengurangkan ketegangan di antara para pengiran dan penduduk tempatan yang sentiasa menentang sikap keras pemerintah Brunei. Ini disebabkan hubungan antara penduduk tempatan dan pemerintah Brunei telahpun ditamatkan oleh Brooke. Penduduk tempatan melihat pentadbiran Brooke lebih stabil dan menunjukkan perubahan. Peralihan pentadbiran pembesar Brunei kepada pentadbiran Brooke menunjukkan berakhirnya diplomasi pembesar Melayu Brunei bersama penduduk tempatan yang telah bermula sejak abad ke-16. Pengambilalihan Sungai Lawas bagi Nicholas Tarling memberi ruang untuk penduduk Sungai Lawas menyedari bahawa mereka bukanlah hamba kepada pengiran tetapi sebagai manusia yang bebas dalam pentadbiran Kerajaan Sarawak. ${ }^{97}$ Penolakan para pengiran dan penduduk Sungai Lawas menjadi punca utama SBUB terpaksa akur untuk melepaskan Sungai Lawas kepada Kerajaan Sarawak. Malah SBUB sendiri tidak yakin Sungai Lawas mampu memberikan pulangan ekonomi yang diharapkan dengan sering berlakunya tentangan penduduk terhadap pemerintah setempat. Selain itu perubahan diplomasi di antara Kerajaan SBUB, dan Kerajaan Sarawak juga turut dipengaruhi oleh kekuatan sumber ekonomi SBUB yang semakin mengecil. ${ }^{98}$ Kelemahan sumber kewangan SBUB menyebabkan Sungai Lawas dengan mudah diserah kepada Keluarga Brooke walaupun Sungai Lawas juga tidak memberikan jaminan ekonomi kepada Kerajaan Sarawak. Walaupun Kerajaan Sarawak berjaya mengambil Sungai Lawas dalam Kerajaan Sarawak namun proses pengambilan telah mengheret masa beberapa tahun sebelum isu Lawas dapat diselesaikan. Pengambilan Sungai Trusan oleh Raja Brooke akhirnya turut membawa masuk Sungai Lawas yang bersempadan dengannya untuk menjadi daerah terakhir yang membentuk sempadan negeri Sarawak seperti yang ada pada hari ini. Daerah Lawas merupakan daerah terakhir dibawa masuk menyertai Kerajaan Sarawak yang telah bermula sejak tahun 1841. 


\section{Lampiran: Lokasi Sungai Trusan dan Sungai Lawas}

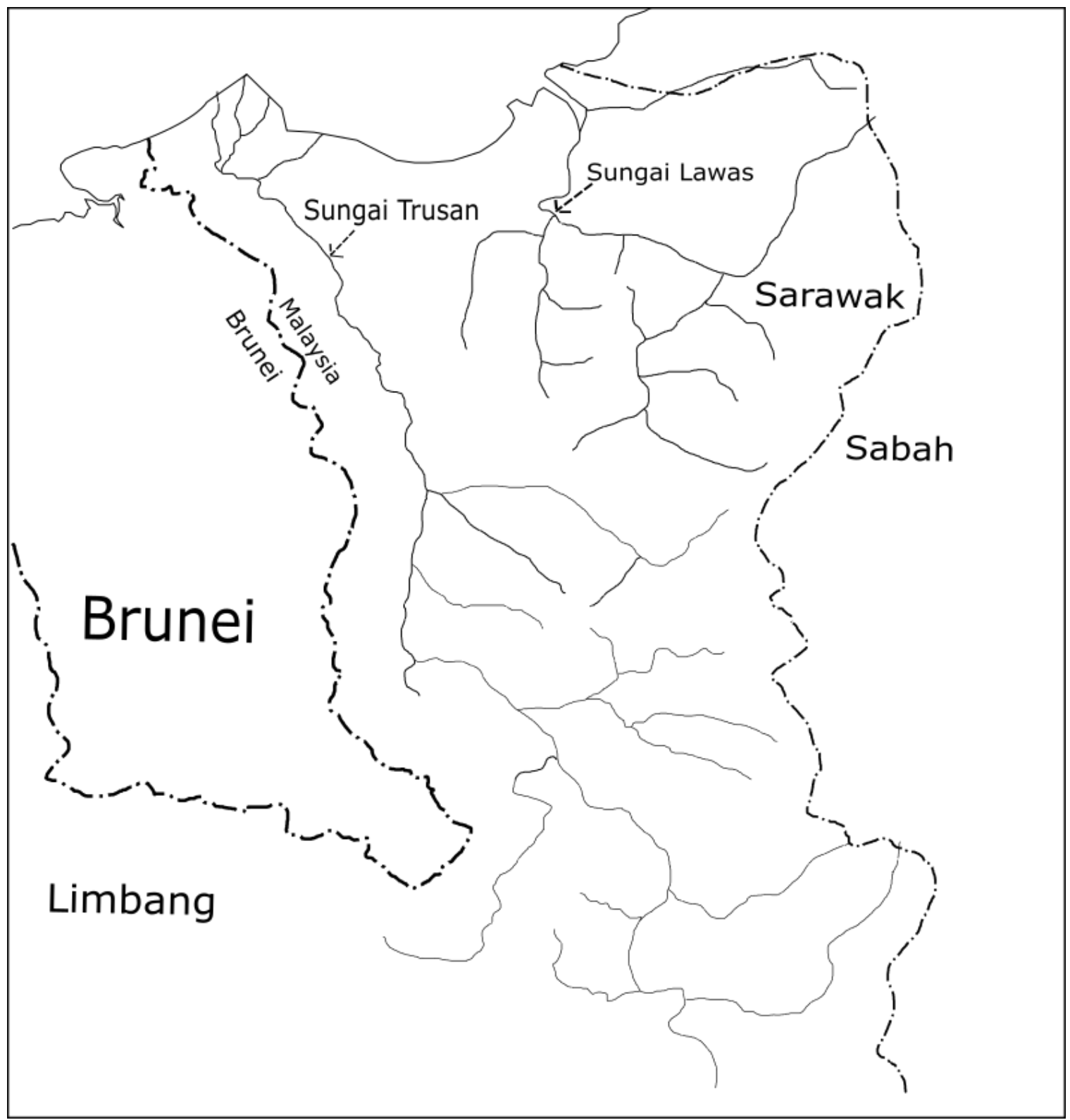

Sumber: FO 572/2, Peta Sarawak, Brunei dan Syarikat Borneo Utara British 1888 


\section{Nota}

${ }^{1}$ Sejarah awal pembentukan Kerajaan Brunei yang menyatakan bahawa Sultan pertama yang beragama Islam bukanlah orang Melayu tetapi merupakan suku-suku peribumi tempatan. Walaupun dinyatakan kaum peribumi itu berkemungkinan Bisaya atau Kelabit-Murut tetapi kemungkinan untuk merujuk kepada orang Lun Bawang tidak boleh diketepikan begitu sahaja. Sila rujuk Tom Harrisson, The Malay of South West Sarawak before Malaysia, Glossgow: University Press, 1970, hlm. 122.

2 British North Borneo Company diterjemahkan sebagai Syarikat Borneo Utara British (SBUB).

${ }^{3}$ Mohammed Yusof Shibli, 'The Descent of Some Kuching Malays', Sarawak Museum Journal, Vol. V, No.2, September 1950, hlm. 263.

4 Antimoni dijmpai pada tahun 1824. Sila lihat Robert Pringle, Rajahs and Rebels: The Ibans of Sarawak under Brooke Rule, 1841-1941, New York: Cornel University Press, 1970, hlm. 68.

5 Surat lantikan James Brooke sebagai Gabenor Sarawak oleh Raja Muda Hashim 24 November 1841 bersamaan dengan 30 Rejab 1257 Hijrah.

${ }^{6}$ Robert Pringle, Rajahs and Rebels: The Ibans of Sarawak under Brooke Rule, 1841-1941, New York: Cornel University Press, 1970, hlm. 66.

7 Steven Runciman, The White Rajahs: A History of Sarawak from 1841 to 1946, London: Cambridge University Press, 1960, hlm. 76.

${ }^{8}$ C.N. Crisswell, Rajah Charles Brooke: Monarch of All He Surveyed, Kuala Lumpur: Oxford University Press, 1978, hlm. 64

9 Peristiwa "Pakatan Orang Melayu" ini diketuai oleh Datu Patinggi Imam Haji Abdul Ghafur di Kuching, Sharif Masahor di Sarikei dan Sungai Rejang dan beberapa pemimpin lain di kawasan Lundu dan Kanowit. Penentangan ini berpunca daripada tindakan Raja Brooke yang cuba menganggu struktur pentadbiran tradisi dengan menukarkannya dengan pemimpin yang baharu yang tidak memiliki pengaruh Brunei. Namun Abddul Ghani dan Juanda berpendapat penentangan ini berpunca daripada Terdapat pendapat lain yang menyatakan sebab-sebab penentangan juga berpunca daripada kebimbangan pengaruh Brooke yang banyak menjejaskan usaha dakwah agama Islam di Sarawak. Sila lihat Zulkiple Abdul Ghani dan Juanda Jaya, 2003, "Peranan Tokoh Agama Dalam Mengorganisasikan Dakwah di Sarawak sebelum Merdeka", dalam Prosiding Nadwah Ulama Nusantara II Sumbangan Ulama dan Tokoh Agama Borneo, Farid Mat Zain et al (pnyt.), Bangi: Fakulti Pengajian Islam, Universiti Kebangsaan Malaysia, 2003.

${ }^{10}$ S. Baring-Gould dan C.A. Bampylde, A History of Sarawak under its two whites Rajahs, London: Hendry Southern \& Co., 1909, hlm. 153-184.

11 "Sir James Brooke's Personal Narative of the Insurrection at Sarawak," Sydney Morning Herald, 31 Julai 1857, hlm. 5.

12 John S. Galbraith, "The Chartering of British North Borneo Company," dlm Journal of British Studies, Vol. 4, No. 2 (May 1965), hlm. 102. Penglibatan Empayar German dan Sepanyol secara agresif menimbulkan kebimbangan kepada Kerajaan British dan perdagangan di Asia dan Pasifik. Sila lihat John M. Ward. 1948. British Policy in the South Paciffic, 1786-1893: A Study in British Policy Towards the South Pacific Islands Prior to the Establishment of Governments by the Great Powers, Sydney: Australasian Pub. Company.

${ }_{13}$ Penglibatan awal di Borneo Utara berlaku apabila Claude Lee Moses dan Johannes terlibat dalam perlombongan antimoni di sekitar Kimanis, Papar dan Bongawan. Kedua-dua mereka telah memohon konsesi selama 10 tahun daripada Sultan Brunei. Disebabkan masalah kewangan pajakan sungai ini telah dijual kepada Joseph W. Torrey, Thomas B. Harris, Wo Hang dan Lee Assing \& Pong Ampong yang akhirnya membentuk The American Trading Company of Borneo. Disebabkan gagal mendapatkan pulangan perniagaan yang baik Torrey menjual kepentingannya kepada Baron Gustav von Overbeck. Sila lihat K. G. Tregonning, Under Chartered Company Rule 
(North Borneo 1881-1946), Singapore: University of Malaya Press, 1958, hlm.5-9.

${ }^{14}$ Von Overbeck (Baron Gustav von Overbeck) merupakan seorang Konsul General Austria di Hong Kong.

15 Alfred Dent merupakan seorang peniaga British yang juga pengasas kepada SBUB bersama dengan Baron Gustav von Overbeck, Konsul General Austria di Hong Kong. Alfred Dent adalah Pengerusi pertama SBUB selepas dibentuk secara rasmi pada tahun 1881-1882. Semasa Alfred Dent menunggu keputusan untuk memperoleh status "Piagam" daripada kerajaan British, Baron Gustav von Overbeck turut berusaha untuk mencari dana bagi membeli saham yang dipegang oleh Dent melalui Kerajaan Austria dan kemudiannya German. Permohonan Dent telah dibawa kepada Bismarck di Parlimen German. Walau bagaimanapun permohonan ini ditolak disebabkan German sedang memberi tumpuan kepada pembentukan Koloni baharu di benua Afrika. Setelah gagal memperoleh dana dan timbul masalah dalam perniagaan, Overbeck telah melepaskan semua pegangan pada September 1880 .

16 Pauncefote pernah bekerja di Hong Kong sebagai Peguam antara tahun 1862-1872. Beliau mulai menyertai Kementerian Luar British pada tahun 1874. Sejak tahun 1882-1889 dia menjawat jawatan Permanent Under Secretary of State for Foreign Affairs.

17 Sir Rutherford Alcock merupakan wakil Kerajaan British di Peking antara tahun 1865-1871. Beliau dilantik menjadi Pengarah kedua British North Borneo Company antara tahun 1882-1893. Sir Rutherford Alcock merupakan pesara yang memiliki hubungan yang baik dengan pegawai-pegawai di Kementerian Luar British.

18 K.G. Tregonning, Under Chartered Company Rule (North Borneo 1881-1946), Singapore: University of Malaya Press, 1958, hlm. 24.

${ }_{19}$ Piagam Diraja ataupun Royal Charter merupakan dokumen formal yang dikeluarkan Kerajaan British sebagai surat kuasa kepada individu ataupun badan korporat bagi menjalankan sesuatu aktiviti atau fungsi khusus yang telah ditetapkan. Fungsi, tanggungjawab ataupun peranan akan dijelaskan melalui kelulusan yang diberikan oleh Kerajaan. Dalam kes SBUB, Piagam boleh di akses

(http://www.lawnet.sabah.gov.my/Lawnet/SabahLaws/Treaties/CharterGrantedToTheBritishNorth BorneoCompany.pdf) diakses pada 17 April 2017.

${ }^{20}$ Charles Brooke (Charles Anthoni Johnson Brooke) merupakan Raja kedua Sarawak selepas James Brooke. Charles Brooke mentadbir Sarawak daripada 3 Ogos 1868 hingga 17 Mei 1917.

${ }^{21}$ William Hood Treacher merupakan Gabenor Borneo Utara yang pertama antara tahun 1881-1887. Pada masa yang sama beliau memegang jawatan sebagai Pemangku Konsul-General di Labuan

${ }^{22}$ Lord Salisbury memegang jawatan sebagai Setiausaha Kementerian Luar British 1878-1880.

23 Walaupun Parti Konservatif telah kalah kepada Parti Liberal dalam pilihan raya di Britain tetapi idea imperialisme dan pengukuhan empayar Britain tetap terus kukuh terutama di kalangan pegawai-pegawai British yang bertugas di Kementerian Luar. Bagi mereka kekukuhan sesebuah empayar bergantung kepada kekuatan dan kekayaan malah peningkatan ekonomi dan ketenteraan dari pesaing Eropah dilihat sebagai isyarat perlunya Britain mempertahankan kedudukan di semua zon lingkungan pengaruh British. Malah dalam sesetengah perkara Britain harus memenangi perlumbaan menguasai sumber dan pasaran yang baharu dibuka.

${ }^{24}$ Piagam DiRaja atau Charter telah dianugerahkan oleh Kerajaan British kepada SBUB pada 1 November 1881 dan Syarikat Borneo Utara British (SBUB) dibentuk secara rasmi pada 4 April 1882.

${ }^{25}$ Crisswell, Rajah Charles Brooke: Monarch of All He Surveyed, Kuala Lumpur: Oxford University Press, 1978, hlm. 160.

${ }^{26}$ Pengiran Temenggung Hashim merupakan salah seorang daripada empat Wazir yang mentadbir Kerajaan Brunei. Selaku pemegang jawatan Pengiran Temenggung beliau bertanggungjawab mentadbir Sungai Limbang dalam jajahan Brunei. Beliau dilantik menjadi Sultan Brunei ke-26 
dengan gelaran Sultan Hashim Jalilul Alam Aqamaddin ibni Sultan Omar Ali Saifuddien II dari 30 Mei 1885-10 Mei 1906.

${ }^{27}$ G. Irwin, Borneo Abad ke-19, Kuala Lumpur: DBP, 1986, hlm. 268.

${ }^{28}$ D.E. Brown, 'Sultan Mumin's Will and Related Documents', Brunei Museum Journal. Vol.III No.2 1974, hlm. 159.

${ }^{29}$ FO371/11, surat daripada G. Hewett kepada Brooke Johnson, 13 Julai 1903. G. Hewett merupakan Konsul British di Labuan.

${ }^{30}$ Leonard Edwards dan Peter W. Stevens, Shorts Stories of the Lawas and Kanowit Districts, Sarawak: Borneo Literature Review, 1971, hlm. 14.

${ }^{31}$ FCO 141/12277, Eastern No. 97: Brunei and Limbang, 1917.

${ }^{32}$ W.H., Treacher, "British Borneo: Sketches of Brunei, Sarawak, Labuan and North Borneo", dalam Royal Asiatic Society, Vol. 20, 1889, hlm. 51

${ }^{33}$ Menurut Runciman, pihak yang membunuh orang Dayak merupakan orang Murut yang juga tinggal di Sungai Trusan. Sila lihat Steven Runciman, The White Rajahs-A History of Sarawak from 1841-1946, hlm. 186-187.

${ }^{34}$ FO 12/61, surat daripada Treacher kepada kepada Secretary of State for Foreign Office, 24 November 1884.

35 F.O. Maxwell merupakan pegawai kanan yang mewakili Kerajaan Sarawak.

${ }^{36}$ W.H., Treacher, British Borneo: Sketches of Brunei, Sarawak, Labuan and North Borneo, hlm. 51.

${ }^{37}$ CO 874/237, surat daripada Treacher kepada R. Alcock, 20 Disember 1884.

38 CO 874/237, surat daripada Treacher kepada R. Alcock, 20 Disember 1884.

39 W.H., Treacher, "British Borneo: Sketches of Brunei, Sarawak, Labuan and North Borneo", dalam Royal Asiatic Society, Vol.20, 1889, hlm. 51. Lihat juga CO 874/237, catatan Alcock, 20 Disember 1884.

${ }^{40}$ R. Haller-Trost, The Brunei-Malaysia Dispute Over Territorial and Maritime Claims, hlm. 12.

${ }^{41}$ Ketika Temenggung Hashim menandatangani perjanjian penyerahan Sungai Trusan baginda berstatus Temenggung dan bakal pengganti Sultan Brunei. Menurut Ranjit Singh dan Treacher, perjanjian ini tidak sah. Ketika Maxwell bertanya persoalan ini kepada Temenggung Hashim beliau menyatakan bahawa Sungai Trusan adalah hak peribadi beliau yang tidak memerlukan cop sultan untuk sebarang urusan. Akan tetapi bagi Treacher tindakan ini bertentangan dengan Perjanjian 1847 di antara Brunei dan British. Sila lihat CO 874/237, Treacher, Gabenor Labuan, 20 Disember 1884.

${ }^{42}$ CO 874/237, Surat daripada Treacher kepada Davies, 20 Disember 1884.

43 CO144/60, R. Alcock kepada Marquis of Salisbury, 15 Julai 1885.

44 CO144/60, R. Alcock kepada J. Pauncefote, 31 Disember 1884.

45 CO 144/60, laporan daripada W.H Treacher, Pemangku Konsul General kepada Earl of Granville, 19 Mac 1885.

46 CO 144/60, Surat daripada Maxwell kepada Treacher, Pemangku Konsul General, 8 Mac 1885.

${ }^{47}$ CO 144/60, Surat daripada Maxwell kepada Treacher, Pemangku Konsul General, 11 Mac 1885.

${ }^{48}$ Raja Brooke menyampaikan rungutan beliau ke atas W.H. Treacher yang didapati bertindak sebagai Pemangku Konsul General di Labuan dan juga pada masa yang sama sebagai Gabenor di SBUB. Brooke kepada Kementerian Luar, 7 November 1884, FO12/63.

${ }^{49} \mathrm{CO} 874 / 50$.

50 N. Tarling, Britain, the Brooke and Brunei, Kuala Lumpur: Oxford Universities Press, 1971, hlm. 366. Lihat juga S. Runciman, The White Rajahs: A History of Sarawak from 1841 to 1946, London: Cambridge University Press, 1960, hlm. 198.

${ }^{51}$ L. Edwards dan P. W. Stevens, Short Stories of the Lawas and Kanowit Districts, Kuching: Borneo Literature Bureau, 1971, hlm. 29. Lihat juga K.G. Tregonning, A History of Modern 
Sabah (North Borneo 1881-1963) Second Edition, Kuala Lumpur: University of Malaya Press, 1965, hlm. 43-44.

${ }^{52}$ The Singapore Free Press and Mercantile Advertiser, 7 October 1901, hlm. 3.

53 The Straits Times, 5 November 1901, hlm. 3. Status sebagai daerah bebas menyebabkan SBUB gagal menyekat kes-kes jenayah yang turut melibatkan penduduk SBUB daripada berleluasa.

54 C.N. Crisswell, 'The Establishment of a Residency in Brunei 1895-1905', dlm. Asian Studies (04), 1972, hlm. 99, 104.

55 Gabenor Ernest Woodford Birch mentadbir SBUB di antara tahun 1901-1903.

${ }^{56}$ FO 371/11, surat daripada G. Hewett, Konsul British di Labuan kepada Brooke Johnson, 13 Julai 1903.

${ }^{57}$ FO 371/11, surat daripada Brooke Johnson kepada Gabenor SBUB, 11 Oktober 1903.

${ }^{58}$ FO881/8725X, Report Enquiry into “Tulin” Rights, Lawas, 1905.

${ }^{59}$ FO 371/11, surat daripada W.C. Cowie, pengerusi SBUB kepada E.P. Gueritz, Pemangku Governor SBUB, 8 Januari 1904.

${ }^{60}$ Wakil daripada sungai Lawas ialah Pengiran Abu Bakar, Pengiran Matusin, dan anak Pengiran Matusin. Perjumpaan turut dihadiri oleh pembesar Melayu Sarawak dan Bampfylde.

${ }^{61}$ FO371/11, surat lantikan sebagai Residen Province Clarke daripada E.P. Gueritz, Gabenor SBUB kepada Brooke Johnson pada 17 Februari 1904. Province Clarke terletak di antara Sungai Trusan dan Sungai Sipitang di bawah pentadbiran SBUB.

${ }^{62}$ FO371/11, surat Raja Brooke kepada Foreign Office, 7 Disember 1904.

63 The Straits Times, 10 Februari 1905, hlm. 5

${ }^{64}$ E. L. Leonard dan P. W. Stevens, Shorts Stories of the Lawas and Kanowit Districts, hlm. 30.

65 Straits Times (Singapura), 1 Mei 1905, hlm. 4

${ }^{66}$ Straits Times (Singapura), 1 Mei 1905, hlm. 4

${ }^{67}$ Petikan surat Brooke Johnson kepada Rajah Brooke, FO371/11.

${ }^{68}$ FO371/11, surat lantikan sebagai Residen Province Clarke daripada E.P. Gueritz, Gabenor SBUB kepada Brooke Johnson, 17 Februari 1904. Province Clarke terletak di antara Sungai Trusan dan Sungai Sipitang di bawah pentadbiran SBUB.

${ }^{69}$ FO 371/11, surat daripada Brooke Johnson kepada Pesuruhjaya Tinggi British Brunei, 4 Mac 1905.

${ }^{70}$ FO 371/11, surat daripada Brooke Johnson kepada Pesuruhjaya Tinggi British Brunei, 4 Mac 1905.

${ }^{71}$ FO 371/11, surat daripada Brooke Johnson kepada Raja Brooke, 16 Mac 1905.

${ }^{72}$ FO 371/11, surat daripada Brooke Johnson kepada Pesuruhjaya Tinggi British Brunei, 17 Mac 1905. Menurut Perjanjian Residen Brunei 1904/1905, Pesuruhjaya Tinggi British bagi Brunei merupakan Gabenor Negeri-negeri Selat yang berpusat di Singapura.

${ }^{73}$ FO 371/11, surat daripada Brooke Johnson kepada Setiausaha peribadi, Governor Negeri-negeri Selat, 7 April 1905.

74 FO 371/11, surat daripada Brooke Johnson kepada Setiausaha peribadi, Governor Negeri-negeri Selat, 25 April 1905.

75 FO371/11, surat daripada Raja Brooke kepada E. Grey, Secretary of State for Foreign Affairs, 15 Februari 1906.

${ }^{76}$ Henry Conway Belfield merupakan pegawai Malayan Civil Service yang berkhidmat di Semenanjung Tanah Melayu antara tahun 1884-1912. Semasa menyiasat isu Sungai Lawas beliau merupakan Residen British di Negeri Selangor. Henry Conway Belfield membuat siasatan berdasarkan arahan daripada Secretary of State for Foreign Affairs pada 4 Mei 19505, FO881/8725X.

77 The Singapore Free Press and Mercantile Advertiser, 8 Jun 1905, hlm. 2.

78 Brooke Johnson telah mengisytiharkan hak beliau ke atas Lawas sejak tahun 1904 melalui surat khabar The Straits Times. Beliau memperolehi hak daripada Pengiran Abu Bakar melalui 
perjanjian 10 tahun yang dibuat pada tahun 1904.

${ }^{79}$ FO881/8725X, Report Enquiry into "Tulin" Rights, Lawas, 1905. Borneo 43/1905, setiap pemegang hak Tulin berhak membuat keputusan sama ada menjual atau sebaliknya tetapi mereka tidak boleh menjualkan hak tersebut kepada negara Eropah yang lain.

${ }^{80}$ FO 881/8725X. perbincangan ini bertumpu kepada pelupusan hak "Tulin" para Pengiran kepada Charles Brooke (Sarawak). Jumlah pembelian hak Tulin yang dipersetujui adalah sebanyak $\$ 6,000$. Mereka turut menyentuh tentang perjanjian yang dibuat oleh Pengiran Abu Bakar bersama dengan Brooke Johnson.

${ }^{81}$ FO 881/8725, Report Upon Enquiry into "Tulin” Rights, Lawas.

${ }^{82}$ FO 881/8725, Report Upon Enquiry into “Tulin” Rights, Lawas.

${ }^{83}$ Surat daripada Charles Brooke, Raja Sarawak kepada John Anderson, Gabenor Negeri-negeri Selat, 15 Julai 1905, Borneo 95/1905.

${ }^{84}$ The Singapore Free Press and Mercantile Advertiser, 8 Jun 1905, hlm. 3.

${ }^{85}$ Borneo 38/1905. Lihat juga The Straits Times, 8 Jun 1905, hlm. 5

86 Borneo 29/1905.

${ }^{87}$ FO371/11, surat Brooke Johnson kepada C.H. Willes Johnson, 11 Julai 1905. Borneo 162/1906, bantahan turut dikemukakan oleh Pengiran Haji Matusin disebabkan tidak bersetuju dengan harga yang ditawarkan.

${ }_{88}$ FO371/11, E.F. Turner \& Sons kepada Secretary of State, Kementerian Luar British pada 3 Januari 1906.

${ }^{89}$ FO371/11, E.F. Turner \& Sons kepada Secretary of State, Kementerian Luar British pada 15 Januari 1906.

${ }^{90}$ FO371/11, E.F. Turner and Sons kepada Secretary of State, Foreign Office, London, 28 Februari 1906.

${ }^{91}$ FO371/11Surat daripada E. Barington, Kementerian Luar British kepada Rajah Brooke, 12 Mac 1906.

${ }^{92}$ FO371/11, surat pengesahan pembayaran Kerajaan Sarawak kepada Kementerian Luar British, 24 Mac 1907. Surat tersebut telah disahkan pada 27 Mac 1906. Johnson telah menerima cek tersebut pada 30 Mac 1906.

${ }^{93}$ FO371/11, surat tuntutan daripada E.F. Turner kepada Secretary of State, 16 Oktober 1906. Lihat juga surat daripada Brooke Johnson kepada Setiausaha peribadi, Gabenor Negeri-negeri Selat, 25 April 1905.

${ }^{94}$ FO371/11, surat daripada Kementerian Luar kepada E. Barrington kepada Messrs E.F. Turner and Sons, 4 April 1906.

95 Sarawak Gazette, 4 Januari 1907.

96 R. Haller-Trost, The Brunei-Malaysia Dispute Over Territorial and Maritime Claims, hlm. 19.

97 N. Tarling, Britain, the Brooke and Brunei, Kuala Lumpur: Oxford Universities Press, 1971, hlm. 539.

98 Salah satu masalah utama SBUB ialah kos pengurusan yang dianggap terlalu besar dan memberikan pulangan yang kecil kepada pemegang saham SBUB. Masalah ini telah dibahasa secara Panjang lebar dalam Mesyuarat Tahunan ke-22 SUBB pada 8 Februari 1894. Sila rujuk MS 283792 (II). 